\title{
Early diagenesis and carbon remineralization in young rift sediment of the Southern Okinawa Trough
}

\author{
Yu-Shih Lin ${ }^{1}$, Huei-Ting Lin ${ }^{2}$, Bo-Shian Wang ${ }^{3}$, Shein-Fu Wu ${ }^{2}$, Pei-Ling Wang ${ }^{2}$, Chih-Lin Wei ${ }^{2}$, \\ Hsiao-Fen Lee ${ }^{4}$, Tefang Lan ${ }^{5}$, Wei-Jen Huang ${ }^{1}$, Song-Chuen Chen ${ }^{6}$, Yunshuen Wang ${ }^{6}$, and \\ Chih-Chieh $\mathrm{Su}^{2, *}$ \\ ${ }^{1}$ Department of Oceanography, National Sun Yat-Sen University, Kaohsiung City, Taiwan \\ ${ }^{2}$ Institute of Oceanography, National Taiwan University, Taipei City, Taiwan \\ ${ }^{3}$ Taiwan Ocean Research Institute, National Applied Research Laboratories, Kaohsiung City, Taiwan \\ ${ }^{4}$ National Center for Research on Earthquake Engineering, National Applied Research Laboratories, Taipei City, Taiwan \\ ${ }^{5}$ Department of Geoscience, National Taiwan University, Taipei City, Taiwan \\ ${ }^{6}$ Central Geological Survey, Ministry of Economic Affairs, New Taipei City, Taiwan
}

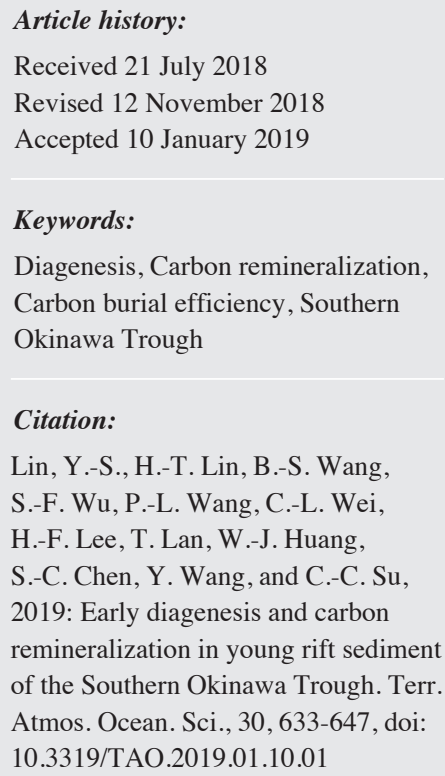

\begin{abstract}
With large topographic gradients, rifted basins serve as efficient traps for particulate matter from adjacent lands and the ocean surface. However, the fate of organic carbon in the sediment, mostly unaltered by the hydrothermal activities known to occur in young rifts, remains poorly understood. In this study, we present an examination of diagenetic activities and carbon remineralization based on the first complete suite of pore-water data of sediment marginally affected by hydrothermal activities in the Southern Okinawa Trough (SOT). The sediment showed an oxygen penetration depth of $1 \mathrm{~cm}$, consumption of $\mathrm{NO}_{3}^{-}$in the top $1 \mathrm{~cm}$, smeared profiles of $\mathrm{Mn}^{2+}$ and $\mathrm{Fe}^{2+}$ with the latter reaching up to $450 \mu \mathrm{mol} \mathrm{L}{ }^{-1}$, and relatively unchanged $\mathrm{SO}_{4}{ }^{2-}$ concentrations with depth. Net production rates of dissolved species resolved from pore-water profiles provide an estimate of $1.68 \pm 0.21 \mathrm{mmol} \mathrm{C} \mathrm{m}^{-2} \mathrm{~d}^{-1}$ as the total carbon remineralization rate in the upper $30 \mathrm{~cm}$ sediment column, with aerobic carbon oxidation being the major pathway. The rate, one order of magnitude lower than that of the adjacent East China Sea, is attributed to the lower bottom-water temperature and carbon flux in the trough. The high carbon burial efficiency of SOT $(68 \%$ of carbon reaching the seafloor and processed thereunder) reflects the combined effects of small mountain rivers and rifting-induced particle trapping.
\end{abstract}

\section{INTRODUCTION}

The role of young rift systems in the global carbon cycle remains contentious. The frequently occurring coastal upwelling, in combination with the topographic gradients that facilitate material transport and burial, render rifted basins efficient traps for particulate carbon from adjacent lands and the ocean surface (e.g., Calvert 1966; Thunell et al. 1994; Sheu et al. 1999; Huh et al. 2006). On the other hand, carbon sequestration in rift sediment can be stunted by extensive magmatism and hydrothermalism (Sibuet et al. 1998; Lizarralde et al. 2011), both of which act to mo-

\footnotetext{
* Corresponding author

E-mail:donccsu@ntu.edu.tw
}

bilize and expel carbon back into seawater (Berndt et al. 2016; Lin et al. 2017). While the latter provides an intriguing aspect regarding how tectonism participates in carbon cycling, it should be noted that the hydrothermal activity is highly spotty at any given time (Lin et al. 2017), and carbon remineralization in the majority of young rift sediment follows early diagenesis under the baseline conditions, i.e., cold temperature with no significant advective fluid flow from deep subseafloor.

The opening of the Okiwana Trough, a curved backarc basin at the convergent boundary between the Eurasian and Philippine Sea Plates, commenced during the late Miocene (9 - 6 Ma; Sibuet et al. 1998). The northbound Kuroshio Current enters the trough from the south, collides with the 
shelf of the southern East China Sea (ECS), and triggers a perennial upwelling center (Liu et al. 1992; Fig. 1). Since the discovery of hydrothermal activities in the central (Sakai et al. 1990) and south sections (Konno et al. 2006) of the basin, much research effort has been devoted to the mineralogy (e.g., Glasby and Notsu 2003), biogeochemistry (e.g., De Beer et al. 2013) and microbiology (e.g., Inagaki et al. 2006) of vents and hydrothermally altered sediments, with scant attention to the baseline condition of early diagenesis. Lin et al. (2002a) first investigated the pore-water chemistry of nonhydrothermally altered sediments in the Southern Okinawa Trough (SOT). For the deep-water (> $1000 \mathrm{~m}$ ) stations, sulfate concentrations showed a mild downward decrease of $2-5 \mathrm{mmol} \mathrm{L}^{-1}$ for the top $100 \mathrm{~cm}$, suggesting that redox reactions thermodynamically more favorable than sulfate reduction might prevail in this horizon. De Beer et al. (2013) reported a shallow $\mathrm{O}_{2}$ penetration depth $(<1 \mathrm{~cm})$ for their reference site sediment, alluding to the transition to $\mathrm{O}_{2}$-depleted regimes in shallow depth. Aside from these two studies, pore-water data that can be used to infer processes other than aerobic respiration and sulfate reduction, such as concentrations of $\mathrm{NO}_{3}^{-}, \mathrm{Mn}^{2+}, \mathrm{Fe}^{2+}$, etc., are missing in the literature. Having the redox regime identified is crucial for subsequent modeling work, which usually relies on the selection of appropriate Redfield stoichiometry for reactions of organic matter remineralization (e.g., Emerson et al. 1980; Boudreau 1987).

This study attempts to portray the diagenetic activity in the near-surface sediment under baseline conditions in the SOT. We chose sites without signatures of liquid $\mathrm{CO}_{2} \mathrm{im}-$ pregnation (to be discussed later) to represent sediment with low levels of hydrothermal alteration. We estimate the contribution of different electron acceptors to carbon remineralization based on the pore-water profiles and calculation of net solute production rates. We then compare our results with published data of the ECS, and discuss factors controlling the diagenetic activity and carbon preservation within the context of regional hydrographic and depositional setting.

\section{MATERIAL AND METHODS}

\subsection{Site Description and Expeditions}

The field sites (Fig. 1; Table 1) were examined during two expeditions: OR1-1164 (25 May to 3 June 2017) and OR1-1194 (29 April to 1 May 2018) by R/V Ocean Research I. As the objective of the cruise OR1-1164 was to retrieve materials affected by hydrothermal activities, sampling sites were chosen broadly based on prior knowledge of subseafloor flow fields and heat flow (Chou et al. 2019; Hsu et al. 2019; this issue), and refined to specific spots based on echosounder images acquired on site. Sites P1-A and P1-T are located in the same hydrothermal patch (Patch "P1") about $10 \mathrm{~km}$ west of the Yonaguni Knoll IV. Towcam images revealed the presence of mineral mounds and che- mosynthetic communities, and the temperature anomalies in the bottom water reached up to $12^{\circ} \mathrm{C}$ (Chou et al. 2019; this issue). Site G2 is situated at the margin of Patch "Gas Center," about $4.5 \mathrm{~km}$ north of Patch P1. This patch features active venting, vent clusters, and multiple mineral mounds. A detailed seafloor survey of this patch is described elsewhere (Chou et al. 2019; this issue). The ${ }^{3} \mathrm{He} /{ }^{4} \mathrm{He}$ ratios for the upper $40 \mathrm{~cm}$ sediment at Sites P1-T and G2 are $1.2-1.4$ and $2.4-2.5 R_{\mathrm{A}}\left(R_{\mathrm{A}}={ }^{3} \mathrm{He} /{ }^{4} \mathrm{He}\right.$ ratio for air), respectively (T. Lan, unpublished data). No helium isotope data are available for the sediment at Site P1-A.

\subsection{Sampling}

Most of the research material was retrieved during OR1-1164. The precise underwater positioning of the corers was achieved by the use of an ultra-short baseline system (Model GAPS NG, iXBlue SAS). Short sediment cores $(<40 \mathrm{~cm})$ with undisturbed sediment-water interface were retrieved by a multicorer (Mega Corer, OSIL). Longer sediment cores $(<200 \mathrm{~cm})$ were recovered with a gravity corer. The coordinates and water depth of the cores used in this study are listed in Table 1.

The cores were processed within $4 \mathrm{~h}$ after retrieval. The overlying water of the multicores was collected with a plastic syringe and then siphoned off. Pore waters were extracted from the intact whole round cores with Rhizon suction samplers $(0.1 \mu \mathrm{m}$ porous polymer, Rhizosphere Research; Seeberg-Elverfeldt et al. 2005). The depth resolution ranged from $1-5 \mathrm{~cm}$ for the multicores and $10-20 \mathrm{~cm}$ for the gravity cores. The split for total dissolved sulfide $\left(\mathrm{H}_{2} \mathrm{~S}\right)$ analysis was immediately fixed with $5 \%(\mathrm{w} / \mathrm{v})$ zinc acetate solution at a volume ratio of 2:1. The subsamples for $\mathrm{Fe}^{2+}$ and $\mathrm{Mn}^{2+}$ analyses were acidified $(\mathrm{pH}<1.8)$ with concentrated $\mathrm{HCl}$ (SEASTAR CHEMICALS). The pore-water samples were kept at $4^{\circ} \mathrm{C}$ [cations, anions, $\mathrm{H}_{2} \mathrm{~S}$, dissolved inorganic carbon (DIC)] or $-20^{\circ} \mathrm{C}$ (nutrients) until analysis.

At each site, parallel cores were dedicated for the analyses of $\mathrm{CH}_{4}$ concentration, porosity, and bulk properties. For $\mathrm{CH}_{4}$ analysis, cut-off plastic syringes were used to collect material from freshly exposed sediment surface, created by cutting the liner of gravity cores into short segments or during slicing of the multicores. The samples were transferred to glass vials containing $1 \mathrm{~N} \mathrm{NaOH}$ solutions, sealed with thick butyl rubber stoppers, and crimp capped. For determination of porosity and total organic carbon (TOC) content, samples were also taken with plastic syringes and transferred to preweighted centrifuge tubes. Samples for total sulfur (TS), total iron $\left(\mathrm{Fe}_{\mathrm{T}}\right)$, and total manganese $\left(\mathrm{Mn}_{\mathrm{T}}\right)$ were stored in polyethylene bags. All samples were kept at $4{ }^{\circ} \mathrm{C}$ until analysis.

\section{3 $\mathrm{O}_{2}$ Profiling}

$\mathrm{O}_{2}$ profiling of the water column at Sites BG, G1, 


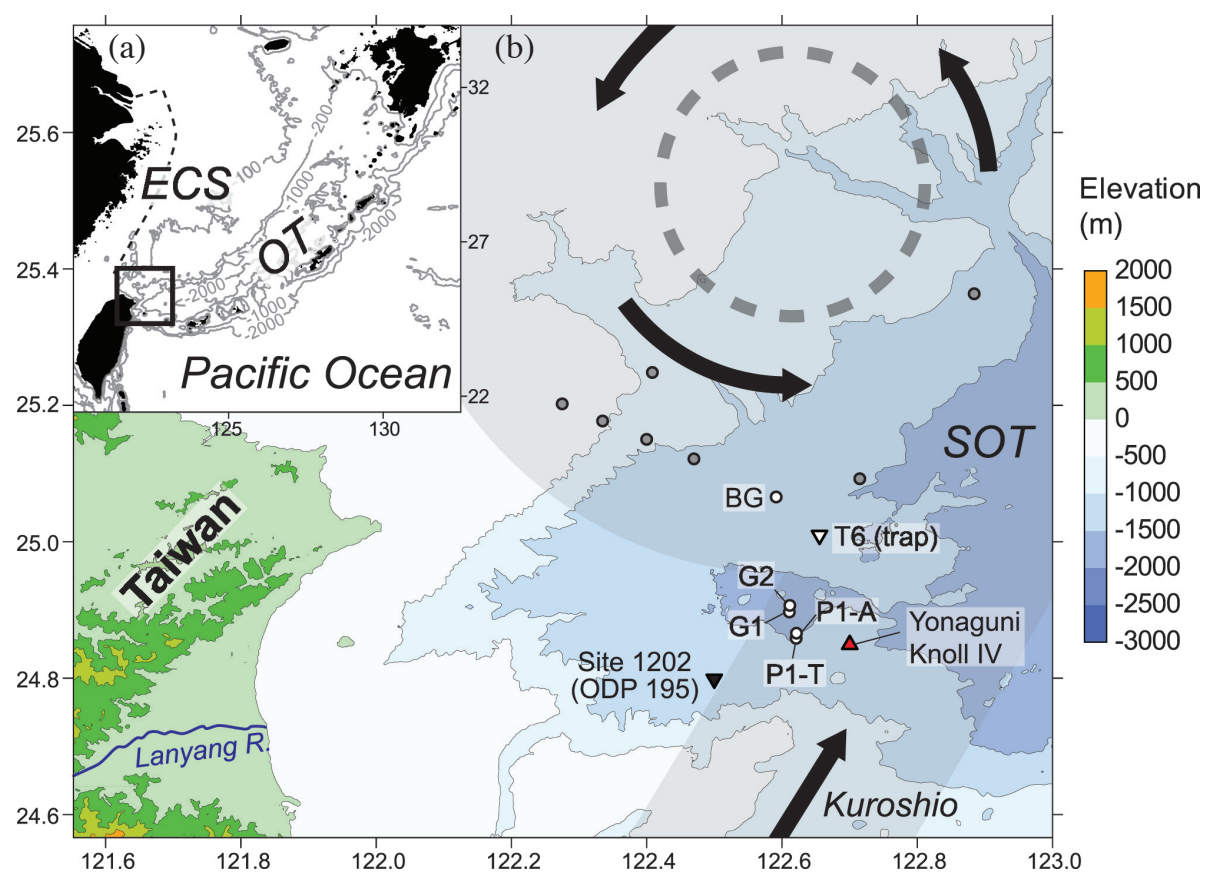

Fig. 1. (a) The location of the Okinawa Trough (OT) relative to the nearby landmasses and the East China Sea (ECS). The dash line stands for the inner shelf region defined in Kao et al. (2003). The square in bold line marks the region enlarged in (b). (b) The Southern Okinawa Trough (SOT) and sampling sites. Site T6 is a sediment trap station reported in previous studies (Sheu et al. 1999; Hsu et al. 2003). Gray dots denote the sites reported in Lin et al. (2002a). The gray shade and arrows indicate the route of the Kuroshio Current and its intrusion onto the East China Sea shelf. The dash circle designates the upwelling center induced by the cyclonic eddy. ODP, Ocean Drilling Program.

Table 1. Coordinates, water depth, and bulk solid-phase properties of the sites

\begin{tabular}{|c|c|c|c|c|c|c|c|c|c|c|}
\hline \multirow{2}{*}{ Site } & \multirow{2}{*}{ Cast type $^{\mathrm{a}}$} & \multirow{2}{*}{ Longitude (E) } & \multirow{2}{*}{ Latitude (N) } & \multirow{2}{*}{ Water depth (m) } & \multirow{2}{*}{ Porosity } & \multirow{2}{*}{$\operatorname{TOC}^{\mathrm{b}}(\% \mathrm{wt})$} & \multirow{2}{*}{ TS (\%wt) } & \multirow{2}{*}{$\mathrm{Fe}_{\mathrm{T}}(\% \mathrm{wt})$} & \multicolumn{2}{|c|}{$\mathbf{M n}_{\mathrm{T}}\left(\mu \mathrm{g} \mathrm{g}^{-1}\right)$} \\
\hline & & & & & & & & & 0 - $1 \mathrm{~cm}$ & $>1 \mathrm{~cm}$ \\
\hline BG & CTD, MUC & $122^{\circ} 35.432^{\prime}$ & $25^{\circ} 03.075^{\prime}$ & 1387 & - & - & - & - & - & - \\
\hline P1-A & MUC & $122^{\circ} 36.764^{\prime}$ & $24^{\circ} 50.921^{\prime}$ & 1512 & $0.65-0.73$ & $0.72 \pm 0.07^{c}$ & $0.10 \pm 0.01$ & $4.33 \pm 0.27$ & 1230 & $529 \pm 32$ \\
\hline P1-T & CTD, MUC & $122^{\circ} 37.222^{\prime}$ & $24^{\circ} 50.752^{\prime}$ & 1490 & $0.60-0.83$ & $0.74 \pm 0.10$ & $0.10 \pm 0.01$ & $4.46 \pm 0.18$ & 2503 & $579 \pm 149$ \\
\hline P1-T & GC & $122^{\circ} 37.204^{\prime}$ & $24^{\circ} 50.683^{\prime}$ & 1490 & $0.57-0.83$ & $0.70 \pm 0.23$ & $0.15 \pm 0.04$ & $4.37 \pm 0.30$ & 584 & $504 \pm 25$ \\
\hline G1 & CTD & $122^{\circ} 36.580^{\prime}$ & $24^{\circ} 53.050^{\prime}$ & 1518 & - & - & - & - & - & - \\
\hline G2 & MUC & $122^{\circ} 36.598^{\prime}$ & $24^{\circ} 53.385^{\prime}$ & 1516 & $0.72-0.84$ & $0.58 \pm 0.06$ & $0.10 \pm 0.01$ & $4.37 \pm 0.30$ & 1003 & $522 \pm 53$ \\
\hline
\end{tabular}

Note: a: CTD, conductivity, temperature and depth instrument; GC, gravity core; MUC, multicore. $b$ : Abbreviations: TOC, total organic carbon; TS, total sulfur; $\mathrm{Fe}_{T}$, total iron; $\mathrm{Mn}_{T}$, total manganese. c: The bulk properties of the solid phase were reported as the mean and standard error of measurements at depth resolutions of $5-20 \mathrm{~cm}$.

and P1-T was carried out using a dissolved oxygen sensor (SBE 43, Sea-Bird Scientific), mounted on a conductivity, temperature, and depth (CTD) instrument. Sediment $\mathrm{O}_{2}$ microprofiling was performed only at Site BG, visited during OR1-1194. Multicores were kept at $4^{\circ} \mathrm{C}$ without stirring for $8 \mathrm{~h}$ before analysis. We used Clark-type microelectrodes (OX-100, Unisense) with an outside tip diameter of $100 \mu \mathrm{m}$. The microelectrodes were two-point calibrated with air-saturated seawater and anoxic sediment pore waters at $3-5 \mathrm{~cm}$ depth.

\subsection{Analysis}

Nutrients $\left(\mathrm{NO}_{3}{ }^{-}\right.$and $\left.\mathrm{NH}_{4}{ }^{+}\right)$were analyzed colorimetrically with a gas-segmented continuous flow auto-analyzer (QuAAtro, SEAL Analytical Inc.). A certified reference material (MOOS-3, provided by the National Research Council, Canada) and in-house seawater nutrient standards (from Merck, traceable to NIST SRMs) were used to check the accuracy and precision. The analytical precision was $1.8 \%$ for $\mathrm{NO}_{3}{ }^{-}$and $5.5 \%$ for $\mathrm{NH}_{4}{ }^{+}$. 
For determination of $\mathrm{Fe}$ and $\mathrm{Mn}$, fluid samples were analyzed on an inductively coupled plasma optical emission spectrometer (Optima 8000, Perkin-Elmer). High-purity standard solutions (High-Purity Standards, Inc.) of multi-elements were used to prepare a series of calibration solutions for Fe and Mn measurements. The analytical precision is 6.4 and $5.8 \%$ for $\mathrm{Fe}$ and $\mathrm{Mn}$, respectively, for overlying water samples, and 4.8 and $1.8 \%$ for pore-water samples.

$\mathrm{SO}_{4}^{2-}$ was analyzed on an ion chromatography system (DIONEX ICS-3000, Thermo), and calibrated with standard solutions prepared from Merck Anionen-Mehrelement standard II. The precision was better than $2 \% . \mathrm{H}_{2} \mathrm{~S}$ was measured by the methylene blue method (American Public Health Association, American Water Works Association and Water Environment Federation 1998) with a precision of $\sim 5 \%$. $\mathrm{CH}_{4}$ was measured with a precision of $\sim 3 \%$ using a gas chromatograph equipped with a flame ionization detector (Model 8610C, SRI Instruments). Detailed setup and discussion of the accuracy, precision and detection limits of this system were described in Lee (2004). Bottom-water DIC was measured by a dissolved inorganic analyzer (Model AS-C3; Apollo SciTech Inc.). Standard seawater (certified reference material prepared by the Scripps Institution of Oceanography) was used to check the accuracy and precision $(0.1 \%)$. Pore-water DIC was determined using a Shimadzu TOCVcph carbon analyzer (Shimadzu Corp.). Repeated analyses of an in-house standard yielded a precision of $2 \%$.

Porosity was determined following the procedure described in Blum (1997), assuming a pore-water density of $1.027 \mathrm{~g} \mathrm{~cm}^{-3}$. For determination of TOC content, dried sediment was decalcified and analyzed with an elemental analyzer (Flash 2000, Thermo Fisher Scientific). Repeated analyses of a certified soil standard (certificate number 133317, Thermo Fisher Scientific) yielded a precision of $3 \%$. Desalted sediment samples were shipped to the Bureau Veritas Mineral Laboratories for the determination of $\mathrm{TS}, \mathrm{Fe}_{\mathrm{T}}$, and $\mathrm{Mn}_{\mathrm{T}}$. The accuracy was assessed with the reference material OREAS 25a (Ore Research \& Exploration Pty. Ltd.).

\subsection{Calculation}

With the assumption that the pore-water profiles were at a steady state, we used the software PROFILE (Berg et al. 1998) to calculate the net production rates of dissolved species. This software accounts for depth-dependent porosity profiles and resolves specific depth horizons in which net production or consumption takes place. The resulting rate values

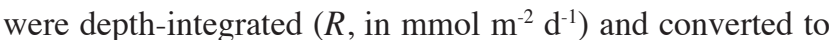
rates of organic carbon remineralization $\left(C_{\text {diag }}\right.$, in $\mathrm{mmol} \mathrm{C} \mathrm{m}^{-2}$ $\mathrm{d}^{-1}$ ) assuming Redfield composition of sedimentary organic matter (e.g., Helder 1989; Bakker and Helder 1993):

$C_{\text {diag }}=\alpha R$ where $\alpha$ is a conversion factor derived from the stoichiometry of organic matter oxidation by different electron acceptors (Table 2; Aller 2014).

The burial rate of organic carbon $\left(C_{\text {burial }}\right)$ across a sediment horizon at the depth of $z(z=30 \mathrm{~cm}$ for the discussion below) was calculated by the following equation (Lin et al. 2000):

$C_{\text {burial }}=\rho(1-\varphi) \omega[\mathrm{TOC}]_{z}$

where $\rho$ is the dry bulk density $\left(2.65 \mathrm{~g} \mathrm{~cm}^{-3}\right), \omega$ the sedimentation rate $\left(0.4 \mathrm{~cm} \mathrm{yr}^{-1}\right.$ for our sites; C. C. Su, unpublished data), and [TOC] $]_{z}$ the TOC content at the depth $z$. The sum of $C_{\text {diag }}$ and $C_{\text {burial }}$, defined as $C_{\text {proc }}$, represents the flux of organic carbon that reaches the seafloor and is processed thereunder (cf. Reimers and Suess 1983, for a detailed definition of different carbon fractions used in the literature of early diagenesis).

\section{RESULTS}

\subsection{Solid-Phase Properties}

The solid-phase properties of the sediment samples are listed in Table 1 . The porosity varied within the range of $0.57-0.84$. The TOC contents were in the range of 0.6 - $0.7 \%$, statistically indistinguishable from previously reported contents of TOC in the SOT sediment ( $\mathrm{p}$-value = 0.07 - 0.28; Welch's t-test, two-tailed; Kao et al. 2003). The TS contents were on average $0.10 \%$ in the multicorer sediment, and slightly higher $(\sim 0.15 \%)$ in the deeper sediment of the gravity core (Table 1$)$. The TS contents were consistent with the sum of pyrite and acid volatile sulfide contents presented in Lin et al. (2002a; p-value $=0.07-0.11)$. The $\mathrm{Fe}_{\mathrm{T}}$ contents were about $4.4 \%$. The $\mathrm{Mn}_{\mathrm{T}}$ contents of the top $1 \mathrm{~cm}$ sediment $\left(1000-2500 \mu \mathrm{g} \mathrm{g}^{-1}\right)$ were 2 - 5 folds higher than those of deeper sediments $\left(\sim 500 \mu \mathrm{g} \mathrm{g}^{-1}\right)$. The $\mathrm{Fe}_{\mathrm{T}}$ and $\mathrm{Mn}_{\mathrm{T}}$ contents were generally comparable to those reported for deep sediment trap samples and surface sediments ( $\mathrm{p}$ value $=0.56-0.81 ;$ Hsu et al. 2003) .

\section{2 $\mathrm{O}_{2}$ Profiles}

Dissolved $\mathrm{O}_{2}$ exhibited a similar pattern in the water column at Sites BG, G1, and P1-T, with the concentration decreasing from $\sim 200 \mu \mathrm{mol} \mathrm{L} \mathrm{L}^{-1}$ in the surface water to 66 - $69 \mu \mathrm{mol} \mathrm{L}{ }^{-1}$ in the bottom water (Fig. 2a). The $\mathrm{O}_{2}$ concentrations of overlying water were $\sim 6 \mu \mathrm{mol} \mathrm{L}{ }^{-1}$ higher than the deep-water values obtained by the CTD casts (Fig. 2b). $\mathrm{O}_{2}$ penetrated down to $1 \mathrm{~cm}$ below the seafloor. The curve was sigmoidal, caused by a top layer $(0-0.08 \mathrm{~cm})$ with enhanced advective transport (advection) overlying deeper layers dominated by diffusive transport (Bakker and Helder 1993).

The mismatch in $\mathrm{O}_{2}$ concentration between the deep 
Table 2. Overall stoichiometric organic matter oxidation reactions discussed in the present study. The coefficients in bold fonts are used in the conversion factor [ $\alpha$ of Eq. (1)].

\begin{tabular}{cc}
\hline Redox process & Overall reaction \\
\hline Aerobic respiration & $\left(\mathrm{CH}_{2} \mathrm{O}\right)_{106}\left(\mathrm{NH}_{3}\right)_{16}\left(\mathrm{H}_{3} \mathrm{PO}_{4}\right)+\mathbf{1 3 8} \mathrm{O}_{2} \rightarrow 106 \mathrm{CO}_{2}+122 \mathrm{H}_{2} \mathrm{O}+16 \mathrm{HNO}_{3}+\mathrm{H}_{3} \mathrm{PO}_{4}$ \\
Nitrate reduction & $\left(\mathrm{CH}_{2} \mathrm{O}\right)_{106}\left(\mathrm{NH}_{3}\right)_{16}\left(\mathrm{H}_{3} \mathrm{PO}_{4}\right)+\mathbf{8 4 . 8} \mathrm{NO}_{3}^{-} \rightarrow 21.2 \mathrm{CO}_{2}+63.6 \mathrm{H}_{2} \mathrm{O}+84.8 \mathrm{HCO}_{3}^{-}+42.4 \mathrm{~N}_{2}+16 \mathrm{NH}_{3}+\mathrm{H}_{3} \mathrm{PO}_{4}$ \\
Manganese reduction & $\left(\mathrm{CH}_{2} \mathrm{O}\right)_{106}\left(\mathrm{NH}_{3}\right)_{16}\left(\mathrm{H}_{3} \mathrm{PO}_{4}\right)+212 \mathrm{MnO}_{2}+318 \mathrm{CO}_{2}+106 \mathrm{H}_{2} \mathrm{O} \rightarrow \mathbf{2 1 2} \mathrm{Mn}^{2+}+424 \mathrm{HCO}_{3}^{-}+16 \mathrm{NH}_{3}+\mathrm{H}_{3} \mathrm{PO}_{4}$ \\
Iron reduction & $\left(\mathrm{CH}_{2} \mathrm{O}\right)_{106}\left(\mathrm{NH}_{3}\right)_{16}\left(\mathrm{H}_{3} \mathrm{PO}_{4}\right)+424 \mathrm{Fe}(\mathrm{OH})_{3}+742 \mathrm{CO}_{2} \rightarrow \mathbf{4 2 4} \mathrm{Fe}^{2+}+848 \mathrm{HCO}_{3}^{-}+318 \mathrm{H}_{2} \mathrm{O}+16 \mathrm{NH}_{3}+\mathrm{H}_{3} \mathrm{PO}_{4}$ \\
Sulfate reduction & $\left(\mathrm{CH}_{2} \mathrm{O}\right)_{106}\left(\mathrm{NH}_{3}\right)_{16}\left(\mathrm{H}_{3} \mathrm{PO}_{4}\right)+53 \mathrm{SO}_{4}^{2-} \rightarrow 53 \mathrm{H}_{2} \mathrm{~S}+106 \mathrm{HCO}_{3}^{-}+\mathbf{1 6 ~ N H}_{3}+\mathrm{H}_{3} \mathrm{PO}_{4}$ \\
\hline
\end{tabular}

(a) $\mathrm{O}_{2}(\mu \mathrm{mol} \mathrm{L}-1)$

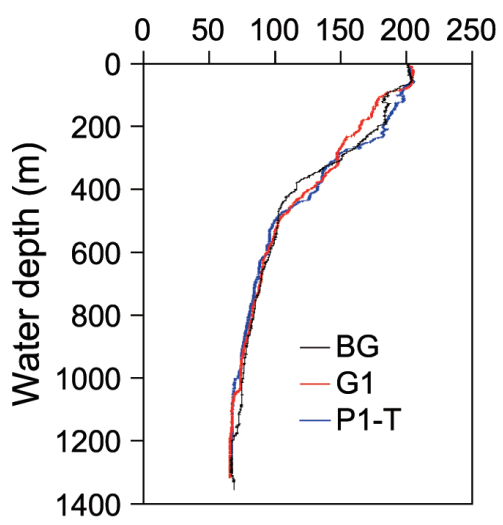

(b) $\mathrm{O}_{2}(\mu \mathrm{mol} \mathrm{L}-1)$

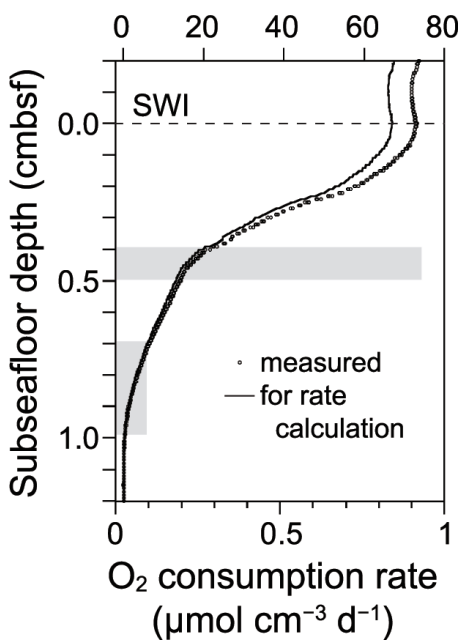

Fig. 2. (a) Distribution of $\mathrm{O}_{2}$ in the water column at three stations. (b) Measutred $\mathrm{O}_{2}$ profile at Site $\mathrm{BG}$ and the adjusted profile for rate calculation. The gray shades denote the net $\mathrm{O}_{2}$ consumption rate (gray shades) in different horizons. SWI, sediment-water interface.

seawater and overlying water has been observed before and attributed to exposure of cores to air during processing on deck (Helder 1989). Using the software PROFILE, we obtained two zones with net $\mathrm{O}_{2}$ consumption (Fig. 2b). The rates are $0.93 \mu \mathrm{mol} \mathrm{cm} \mathrm{cm}^{-3} \mathrm{~d}^{-1}$ at $0.4-0.5 \mathrm{~cm}$ and $0.09 \mu \mathrm{mol} \mathrm{cm}{ }^{-3} \mathrm{~d}^{-1}$ at $0.7-1.0 \mathrm{~cm}$. Following previous work (e.g., Hyun et al. 2017), we attributed the upper zone to $\mathrm{O}_{2}$ consumption by aerobic organotrophic respiration, and the deeper zone to reoxidation of reduced substances.

\subsection{Pore-Water Profiles}

$\mathrm{NO}_{3}{ }^{-}$concentration in the topmost pore-water samples (Fig. 3) was $10-20 \mu \mathrm{mol} \mathrm{L}^{-1}$ lower than the deep seawater $\mathrm{NO}_{3}^{-}$content (36 $\mu \mathrm{mol} \mathrm{L}^{-1}$; Wong et al. 1989), indicating active denitrification in the topmost $1 \mathrm{~cm}$ layer. $\mathrm{NO}_{3}{ }^{-}$concentration decreased exponentially with depth and was no longer detectable below $15-20 \mathrm{~cm}$. A subsurface maximum was found at 15 and $13 \mathrm{~cm}$ in the profile of Site P1-T and G2, respectively. This feature has been found in other deepsea sediments (e.g., Bakker and Helder 1993; Hyun et al. 2017) and is attributed to bioirrigating burrows. $\mathrm{NH}_{4}{ }^{+}$ex- hibited a downcore increasing trend, rising from a submicromolar level in the bottom water to $100-380 \mu \mathrm{mol} \mathrm{L}^{-1}$ at the bottom of the multicores.

Dissolved Mn concentration was $<1 \mu \mathrm{mol} \mathrm{L^{-1 }}$ in the deep seawater. In the interstitial space, Mn (presumably in the form of $\mathrm{Mn}^{2+}$ ) accumulated rapidly, reaching 45 - $65 \mu \mathrm{mol} \mathrm{L} \mathrm{L}^{-1}$ in the top $5-6 \mathrm{~cm}$. Below this top accumulation zone, $\mathrm{Mn}^{2+}$ concentrations decreased by $\sim 20 \mu \mathrm{mol} \mathrm{L} \mathrm{L}^{-1}$ and then continued to increase with depth. In the long gravity core of Site P1-T, the maximum $\mathrm{Mn}^{2+}$ concentration was reached at $55 \mathrm{~cm}$, below which a decreasing trend with depth ensued. Dissolved Fe concentration was below the detection limit in the deep seawater. In the multicores, dissolved $\mathrm{Fe}$ (presumably in the form of $\mathrm{Fe}^{2+}$ ) concentration increased with depth and reached $185-450 \mu \mathrm{mol} \mathrm{L}^{-1}$ at the core bottom. In the gravity core of Site P1-T, $\mathrm{Fe}^{2+}$ concentration showed a maximum at a depth of $60 \mathrm{~cm}$ and decreased with depth to $\sim 90 \mu \mathrm{mol} \mathrm{L}^{-1}$ at $115 \mathrm{~cm}$.

Like the profiles of deep-water stations reported in Lin et al. (2002a), $\mathrm{SO}_{4}{ }^{2-}$ concentrations were relatively constant, deviating less than $2 \mathrm{mmol} \mathrm{L}^{-1}$ from the bottom-water concentration throughout the cored sediment. $\mathrm{H}_{2} \mathrm{~S}$ concentrations 
(a) P1-A
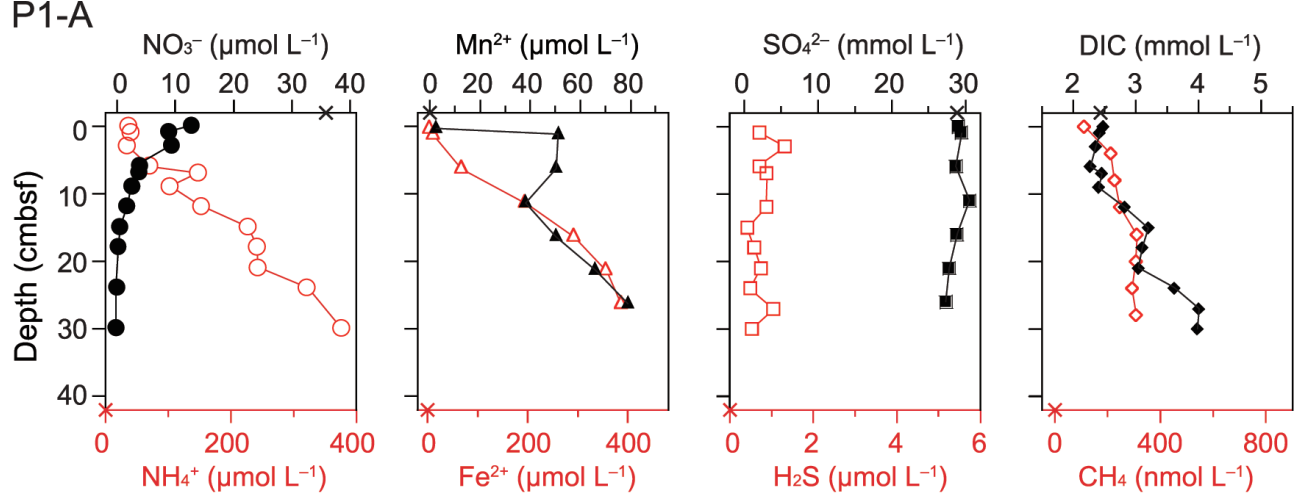

(b) P1-T
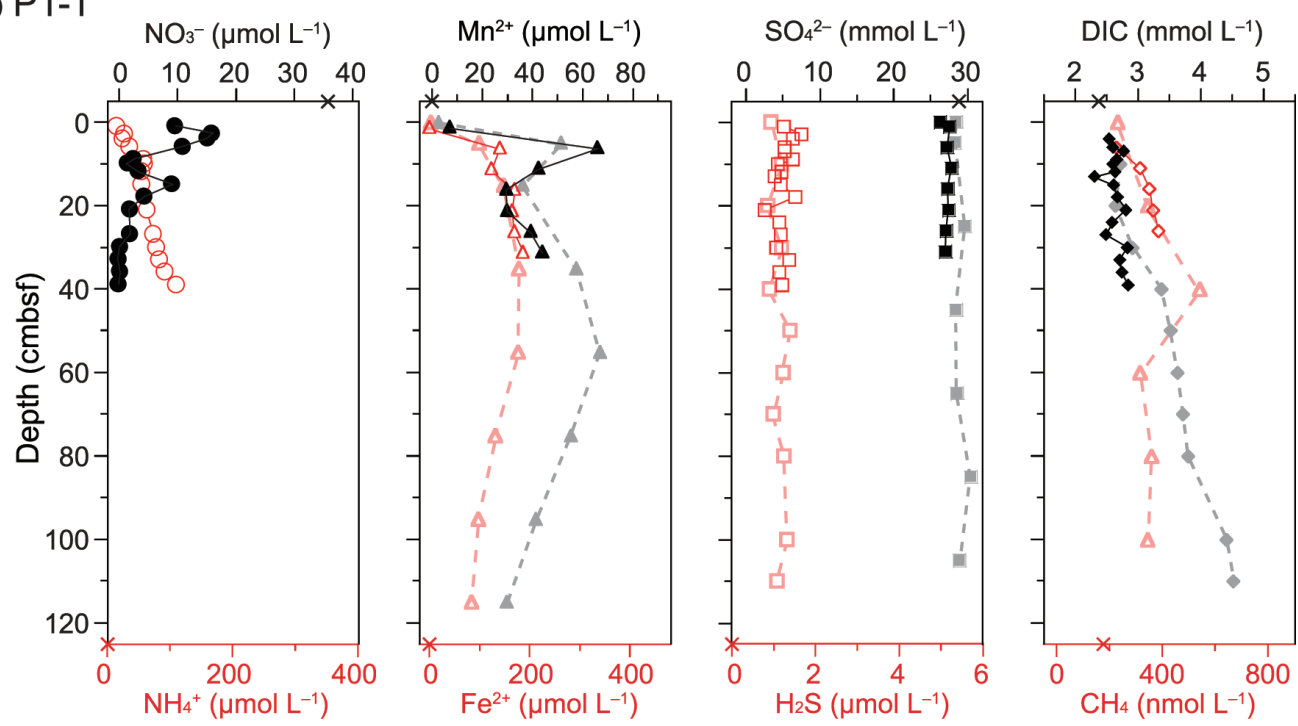

(c) G2
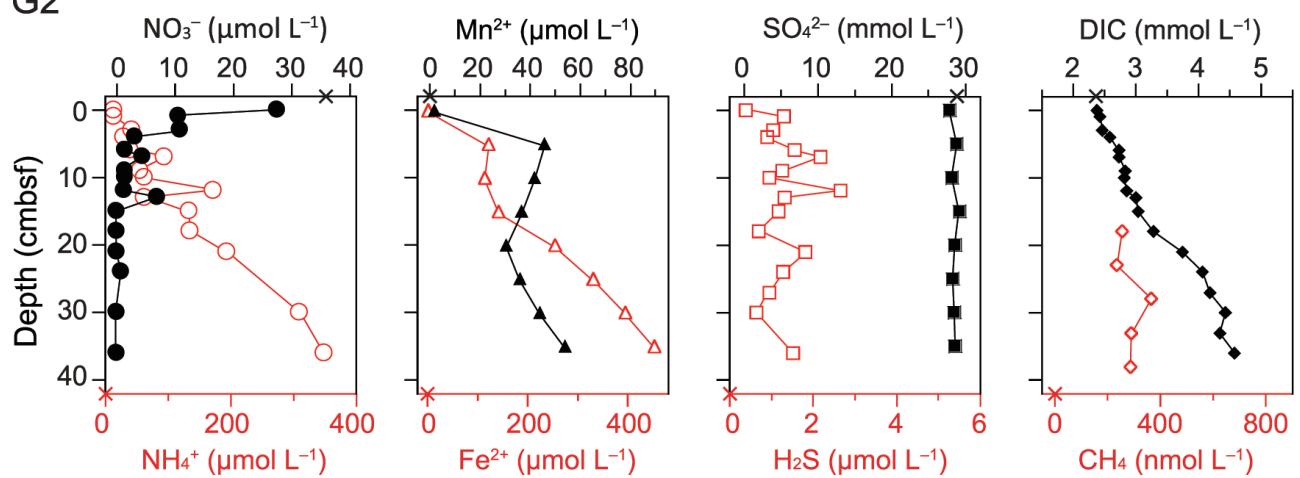

Fig. 3. Results of pore-water analyses at Sites (a) P1-A, (b) P1-T, and (c) G2. Gray and light red symbols with dash line denote data from the gravity core. Crosses on the $\mathrm{x}$ axes denote the solute concentration in the bottom water. 
were constantly low but detectable $\left(0.4-2.7 \mu \mathrm{mol} \mathrm{L}^{-1}\right)$. Some of the measurements might have been affected by the colored (slightly yellowish) substance in the pore water. The colored substance may be iron hydroxide precipitates, but we did not perform any correction on the photometric data.

At Sites P1-A and G2, DIC exhibited a downcore increasing trend, rising from deep seawater concentrations of $\sim 2.4 \mathrm{mmol} \mathrm{L}^{-1}$ to $4-4.5 \mathrm{mmol} \mathrm{L}^{-1}$ at the bottom of the multicore. Site P1-T showed a much gentler trend of DIC, reaching only $2.8 \mathrm{mmol} \mathrm{L}^{-1}$ at the bottom of the multicore and $4.5 \mathrm{mmol} \mathrm{L}^{-1}$ at the bottom of the gravity core. Pore-water $\mathrm{CH}_{4}$ concentrations were in the range of $110-425 \mathrm{nmol} \mathrm{L}^{-1}$ and exhibited a downcore increasing trend in the multicores. The concentration range is orders of magnitude lower than the typical range known for methanogenic sediment (millimolar scale; e.g., Lin et al. 2012). Of note is that dissolved $\mathrm{CH}_{4}$ concentrations in the deep water of SOT are up to 100 - $500 \mathrm{nmol} \mathrm{L}^{-1}$ (Hsu et al. 2003). Therefore, a portion of the pore-water $\mathrm{CH}_{4}$ might have originated from the entrained bottom water during particle deposition.

Using the software PROFILE, we computed the depth-integrated production rates of $\mathrm{NO}_{3}{ }^{-}, \mathrm{Mn}^{2+}, \mathrm{Fe}^{2+}$ and $\mathrm{NH}_{4}{ }^{+}$(Table 3). The consumption rates of $\mathrm{NO}_{3}^{-}$(234 $\left.436 \mu \mathrm{mol} \mathrm{m}^{-2} \mathrm{~d}^{-1}\right)$ are higher than the production rates of dissolved metals $\left(24-160 \mu \mathrm{mol} \mathrm{m}^{-2} \mathrm{~d}^{-1}\right)$. The production rates of $\mathrm{NH}_{4}{ }^{+}$exhibited inter-site variations, ranging from 23 $76 \mu \mathrm{mol} \mathrm{m}{ }^{-2} \mathrm{~d}^{-1}$.

\section{DISCUSSION}

Although the initial purpose of the sampling campaign was to investigate the geochemistry of sediments altered by hydrothermal activities, the bulk properties of our sediment, such as TOC, TS, $\mathrm{Fe}_{\mathrm{T}}$ and $\mathrm{Mn}_{\mathrm{T}}$ (Table 1), are all statistically indistinguishable from the values reported previously for regular SOT sediment. Moreover, in spite of the elevated values of ${ }^{3} \mathrm{He} /{ }^{4} \mathrm{He}$ ratios (T. Lan, unpublished data), the pore-water profiles did not exhibit signatures known for liquid $\mathrm{CO}_{2}$-impregnated sediments, such as exceptionally high total alkalinity or DIC at the tens of millimolar level, and the rapid decrease of $\mathrm{SO}_{4}{ }^{2-}$ within the upper $30 \mathrm{~cm}$ (De Beer et al. 2013). Liquid $\mathrm{CO}_{2}$ impregnation and the associated geochemical characteristics are the main features of hydrothermally altered sediment in this backarc basin (Inagaki et al. 2006; De Beer et al. 2013). Therefore, we conclude that our sites are only marginally affected by hydrothermal activities, and the pore-water profiles reflect the general diagenetic condition in the deep SOT.

Pore-water profiles are sensitive to the quantity and quality of remineralizable carbon, the supply of which is governed by regional oceanographic and depositional environments. Based on bulk properties and molecular proxies, several studies support the notion that a major fraction of organic matter in SOT sediment originates from the inner shelf of ECS (Kao et al. 2003; Chen et al. 2017). The shelfexported organic matter that ultimate reaches the deep SOT might be extensively processed, but the regional upwelling center (Fig. 1) may add degradable carbon to the seafloor. To clarify the effects of these factors on the observed diagenetic activity, in the following discussion, we compare our data primarily with those of ECS sediment. Where appropriate, other systems at comparable water depths are also discussed.

\subsection{Early Diagenetic Features of SOT Sediments}

The pore-water profiles in the short multicores (Figs. 2 and 3) have the following key features for dissolved species related to terminal electron accepting processes. $\mathrm{O}_{2}$ was exhausted a depth of $1 \mathrm{~cm}$ with a change in the concentration gradient at $0.45 \mathrm{~cm}$, associated with a zone of active $\mathrm{O}_{2}$ consumption. $\mathrm{NO}_{3}{ }^{-}$consumption occurred even with the presence of $\mathrm{O}_{2}$ in the top $1 \mathrm{~cm}$, and $\mathrm{NO}_{3}^{-}$exhaustion depths occurred at $\sim 15 \mathrm{~cm}$. Mn and Fe reduction occurred within $1-5 \mathrm{~cm}$ where $\mathrm{NO}_{3}^{-}$concentrations remains abundant $\left(10-15 \mu \mathrm{mol} \mathrm{L}^{-1}\right)$. Mn and Fe profiles are highly smeared, increased to a maximum but decreased again with depths (Fig. 3). The downward decreasing trend in deeper sediment is interpreted as the solubility control of authigenic phases, such as Mn carbonates and Fe sulfides (Canfield et

Table 3. Depth-integrated net production rates $\left(R\right.$, in mmol $\left.\mathrm{m}^{-2} \mathrm{~d}^{-1}\right)$ of dissolved species in the upper $30 \mathrm{~cm}$ sediment. Negative rate values represent net consumption. Depth range (in $\mathrm{cm}$ ) is the range of reaction zones identified by the software PROFILE (Berg et al. 1998).

\begin{tabular}{c|cc|cc|cc|cc}
\hline \multirow{2}{*}{ Species } & \multicolumn{2}{|c|}{ BG } & \multicolumn{2}{|c|}{ P1-A } & P1-T & \multicolumn{2}{|c}{ G2 } \\
\cline { 2 - 8 } & Depth range & $\boldsymbol{R}$ & Depth range & $\boldsymbol{R}$ & Depth range & $\boldsymbol{R}$ & Depth range & $\boldsymbol{R}$ \\
\hline $\mathrm{O}_{2}$ & $0.40-0.50$ & -1.20 & - & - & - & - & - & - \\
$\mathrm{NO}_{3}^{-}$ & - & - & $0-2$ & -0.44 & $0-2$ & -0.28 & $0-2$ & -0.23 \\
$\mathrm{Mn}^{2+}$ & - & - & $0-2$ & 0.16 & $5-7$ & 0.03 & $0-7$ & $0.02^{\mathrm{a}}$ \\
$\mathrm{Fe}^{2+}$ & - & - & $0-16$ & 0.03 & $3-7$ & 0.08 & $0-6$ & 0.13 \\
$\mathrm{NH}_{4}^{+}$ & - & - & $10-25$ & 0.05 & $10-12$ & 0.02 & $25-30$ & 0.08 \\
\hline
\end{tabular}

Note: a: Rates underestimated due to a lower sampling resolution. 
al. 1993). The zigzag feature of $\mathrm{Mn}^{2+}$ profiles is not uncommon in marine sediment (e.g., Canfield et al. 1993), but the underlying reason is barely discussed. This is possibly due to the fact that both $\mathrm{Mn}^{2+}$ and $\mathrm{MnO}_{2}$ can couple to multiple redox species other than organic matter (Aller 2014), complicating the interpretation of $\mathrm{Mn}$ data as a manifestation of a carbon oxidation process. Sulfate reduction is not significant because $\mathrm{SO}_{4}{ }^{2-}$ concentrations are relatively unchanged, and the methanogenic zone is below the examined interval $(125 \mathrm{~cm})$. The observation is consistent with the data of ODP Site 1202 (from Ocean Drilling Program Leg 195), drilled $11 \mathrm{~km}$ southeast to our sites (Fig. 1). The long core showed that the sulfate-methane interface is as deep as $10 \mathrm{~m}$ (Mottl 2005).

\subsection{Comparison of Pore-Water Profiles of SOT and ECS Sediments}

The features summarized above differ in several aspects from those reported for ECS sediments. Most of the pore-water geochemical studies of ECS are based on sediments retrieved in the inner shelf (Fig. 1) during summer. The water depths of ECS are shallow (10 - $63 \mathrm{~m})$ and thus the bottom water is characterized with high $\mathrm{O}_{2}$ concentrations (100 - $220 \mu \mathrm{mol} \mathrm{L}^{-1}$; Chen et al. 2007) and low $\mathrm{NO}_{3}$ concentrations (mostly $<10 \mu \mathrm{mol} \mathrm{L}^{-1}$; Gong et al. 2000) except the estuaries, where anthropogenic input is significant. Nevertheless, the $\mathrm{O}_{2}$ penetration depth is as shallow as 0.3 $-0.7 \mathrm{~cm}$ in the reported sediment profiles, giving rise to steep concentration gradients (Cai et al. 2014). $\mathrm{NO}_{3}{ }^{-}$profiles are highly heterogeneous for the shelf sites. Some showed an extended $\mathrm{NO}_{3}{ }^{-}$-rich upper layer up to $10 \mathrm{~cm}$ in thickness, others showed a rapid decrease in the top $5 \mathrm{~cm}$, and still others had subsurface $\mathrm{NO}_{3}^{-}$maximums (Song et al. 2013; Zhao et al. 2017). Observable gradients of $\mathrm{SO}_{4}{ }^{2-} / \mathrm{Cl}^{-}$ratio were found in about half of the published profiles (Zhao et al. 2017). The gentler $\mathrm{O}_{2}$ gradients, deeper $\mathrm{O}_{2}$ penetration and a lack of marked $\mathrm{SO}_{4}{ }^{2-}$ concentration gradients indicate lower diagenetic activity in SOT sediments than in inner shelf sediments of ECS.

Like SOT sediment, most of the $\mathrm{Mn}^{2+}$ profiles of ECS showed a steep gradient in the top $1 \mathrm{~cm}$ and reached maximum levels of $30-80 \mu \mathrm{mol} \mathrm{L}^{-1}$ (Zhao et al. 2017). However, a downcore decreasing trend of $\mathrm{Mn}^{2+}$ below the subsurface maximum could be readily observed in the $30 \mathrm{~cm}$ sediment column, alluding to a higher flux of substances for precipitating $\mathrm{Mn}^{2+}$ out of the aqueous phase in ECS sediments than in SOT sediments. A change in curvature could also be seen in the $\mathrm{Fe}^{2+}$ profiles, with subsurface maximum mostly $<100 \mu \mathrm{mol} \mathrm{L}^{-1}$ (Zhao et al. 2017).

Interpretation of the differences in $\mathrm{Mn}^{2+}$ and $\mathrm{Fe}^{2+}$ profiles from SOT and ECS is less straightforward, as the abundance of these solutes also depends on the supply of reactive metal species in the solid phase and co-precipitation agents (e.g., $\mathrm{CO}_{3}{ }^{2-}$ and $\mathrm{S}^{2-}$ ) in the pore fluids. The extremely high $\mathrm{Fe}^{2+}$ concentrations (up to $450 \mu \mathrm{mol} \mathrm{L}{ }^{-1}$ ) and the smeared $\mathrm{Fe}^{2+}$ profiles in SOT sediments are distinct from $\mathrm{Fe}^{2+}$ in other continental slope sediments at comparable water depths, where $\mathrm{Fe}^{2+}$ contents barely exceed $50 \mu \mathrm{mol} \mathrm{L}{ }^{-1}$ (e.g., Helder 1989; Küster-Heins et al. 2010; Hyun et al. 2017). The $\mathrm{Mn}_{\mathrm{T}}$ and $\mathrm{Fe}_{\mathrm{T}}$ contents in the surface sediment of our cored sites are comparable to those in the inner shelf sediments of the ECS (Lin et al. 2002b; Zhu et al. 2012). However, at the species level, Hsu et al. (2003) reported enrichment of reactive $\mathrm{Mn}$ and $\mathrm{Fe}$ in the settling particles of the sediment trap station T6 (Fig. 1) because of incorporation of hydrothermally derived particles. In their $1340-\mathrm{m}$ trap samples, the sum of exchangeable, carbonate, and easily-to-moderately reducible $\mathrm{Mn}$ and $\mathrm{Fe}$ fractions constitutes $86 \pm 6$ and 41 $\pm 1 \%$, respectively, of the $\mathrm{Mn}_{\mathrm{T}}$ and $\mathrm{Fe}_{\mathrm{T}}$. If the deep-water trap samples are good approximations of surface sediment samples in terms of solid-phase composition, surface sediments of SOT would be enriched in reactive Fe relative to those of ECS (33 $\pm 4 \%$; Zhu et al. 2012). Therefore, the pore-water $\mathrm{Fe}^{2+}$ features of SOT is attributed to (1) the addition of hydrothermally-derived $\mathrm{Fe}$, which provides for the iron reducing communities, and (2) the sluggish sulfate reduction (Lin et al. 2002a), which supplies $\mathrm{H}_{2} \mathrm{~S}$ slowly for removing dissolved $\mathrm{Fe}$ from soluble phase.

By corollary, one would anticipate the same smeared shape and high concentrations for the $\mathrm{Mn}^{2+}$ profiles. The SOT sediments do have smeared $\mathrm{Mn}^{2+}$ profiles relative to ECS sediments, but the maximum concentrations are not significantly elevated. This could be either due to leakage of $\mathrm{Mn}^{2+}$ from the sediment into overlying water (Hyun et al. 2017), strong adsorption of $\mathrm{Mn}^{2+}$ onto Mn oxides (Canfield et al. 1993), or other as yet unaccounted-for processes. The impact of hydrothermally derived Mn precipitates on diagenesis, if present, remains elusive and awaits clarification via incubation-based approaches.

\subsection{Partitioning of Carbon Oxidation Pathways}

One classical approach of quantifying diagenetic activities is to convert production or consumption rates of redoxrelated dissolved species into rates of organic carbon remineralization by the use of Redfield stoichiometry [Eq. (1)]. This approach, though not as accurate as tracer techniques (Reimers and Suess 1983), provides an initial quantitative assessment of diagenetic activities. As pore-water analysis is more frequently carried out than tracer experiments, this approach furnishes a common basis for comparison across different systems.

We calculated the $C_{\text {diag }}$ rates (Table 4 ) by different electron acceptors using the depth-integrated net production or consumption rates of dissolved species (Table 3). Although sedimentary $\mathrm{O}_{2}$ data are not available at Sites P1-A, P1-T, and $\mathrm{G} 2$, the $\mathrm{O}_{2}$ consumption rate of Site BG is only slightly 
lower than that determined for regular sediment in the nearby Yonaguni Knoll IV (1.51 $\mathrm{mmol} \mathrm{O}_{2} \mathrm{~m}^{-2} \mathrm{~d}^{-1}$; calculated from De Beer et al. 2013). It is possible that the actual $\mathrm{O}_{2}$ consumption rates of the other three sites fall around the values determined for Site BG and Yonaguni Knoll IV, and minor deviations in $\mathrm{O}_{2}$ consumption rates from the Site $\mathrm{BG}$ value would not change our conclusions. The $\mathrm{SO}_{4}{ }^{2-}$ gradient is barely detectable except for Site P1-A, which showed a decrease in $\mathrm{SO}_{4}{ }^{2-}$ by $2 \mathrm{mmol} \mathrm{L}^{-1}$ at the core bottom. The production of $\mathrm{NH}_{4}^{+}$, instead, exceeds the theoretical contribution by Fe reduction (cf. Table 2 for the stoichiometry). Therefore, we used the excess $\mathrm{NH}_{4}{ }^{+}$production rate, i.e., the rate that cannot be accounted for by $\mathrm{Fe}$ reduction, to estimate of the amount of carbon oxidized by sulfate reduction. The resulting $C_{\text {diag }}$ rates of $0.30 \pm 0.17 \mathrm{mmol} \mathrm{C} \mathrm{m}^{-2} \mathrm{~d}^{-1}$ agree within uncertainties with the radioactive tracer-based estimate $\left(0.34 \mathrm{mmol} \mathrm{C} \mathrm{m}^{-2} \mathrm{~d}^{-1}\right.$ for the deep-water station; calculated from Lin et al. 2002a). The total $C_{\text {diag }}$ rates for the upper $30 \mathrm{~cm}$ sediment column are 1.68 $\pm 0.21 \mathrm{mmol} \mathrm{C} \mathrm{m}^{-2} \mathrm{~d}^{-1}$. The total $C_{\text {diag }}$ rates are low, being only $\sim 70 \%$ of the values of the Savu Basin sediments in Indonesia $\left(2.42 \pm 0.51 \mathrm{mmol} \mathrm{C} \mathrm{m}{ }^{-2} \mathrm{~d}^{-1} ; \sim 2000 \mathrm{~m}\right.$ water depth; Helder $1989)$ or the aerobic carbon oxidation rates of East Sea sediments in Northeast Asia $\left(2.52 \pm 1.65 \mathrm{mmol} \mathrm{C} \mathrm{m}^{-2} \mathrm{~d}^{-1} ; 1500\right.$ - $2000 \mathrm{~m}$ water depth; Hyun et al. 2017). The contribution of different electron acceptors, in decreasing order of relative importance, is $\mathrm{O}_{2}(55 \pm 7 \%)>\mathrm{NO}_{3}{ }^{-}(24 \pm 8 \%) \approx \mathrm{SO}_{4}{ }^{2-}(18 \pm$ $10 \%)>$ Mn oxides $(2 \pm 2 \%) \approx \mathrm{Fe}$ oxides $(1.2 \pm 0.8 \%)$.

A similar practice was performed using literature data of inner shelf sediments in the ECS (Table 5). We are aware that due to seasonal variations in weather and current conditions, the pore-water profiles are not under a steady state at an annual time scale. Therefore, we based our calculation only on data of one single season, and the results should not be extrapolated to annual estimates. We obtained a total

Table 4. Areal rates of carbon oxidation via early diagenesis $\left(C_{\text {diag }}\right)$, derived from the depth-integrated net production rates of dissolved species listed in Table 3, for the upper $30 \mathrm{~cm}$ sediment.

\begin{tabular}{|c|c|c|c|c|c|c|c|c|c|}
\hline \multirow{3}{*}{ Carbon remineralization by: } & \multirow{3}{*}{ Conversion factor $(\alpha)^{\mathrm{a}}$} & \multicolumn{4}{|c|}{$C_{\text {diag }}\left(\mathrm{mmol} \mathrm{C} \mathrm{m}^{-2} \mathrm{~d}^{-1}\right)$} & \multicolumn{4}{|c|}{ Average over sites } \\
\hline & & \multirow{2}{*}{ BG } & \multirow{2}{*}{ P1-A } & \multirow{2}{*}{ P1-T } & \multirow{2}{*}{ G2 } & \multicolumn{2}{|c|}{ 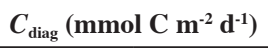 } & \multicolumn{2}{|c|}{ Relative importance (\%) } \\
\hline & & & & & & Mean & $\boldsymbol{\sigma}$ & Mean & $\boldsymbol{\sigma}$ \\
\hline Aerobic respiration & $106 / 138$ & 0.92 & - & - & - & 0.92 & - & 55 & 7 \\
\hline $\mathrm{NO}_{3}^{-}$reduction & $106 / 84.8$ & - & 0.54 & 0.35 & 0.29 & 0.40 & 0.13 & 24 & 8 \\
\hline Mn reduction & $106 / 212$ & - & 0.08 & 0.02 & $0.01^{\mathrm{b}}$ & 0.04 & 0.04 & 2 & 2 \\
\hline Fe reduction & $106 / 424$ & - & 0.007 & 0.02 & 0.03 & 0.02 & 0.01 & 1.2 & 0.8 \\
\hline $\mathrm{SO}_{4}^{2-}$ reduction & $106 / 16$ & - & 0.31 & 0.14 & 0.47 & 0.30 & 0.17 & 18 & 10 \\
\hline Total & - & - & - & - & - & 1.68 & 0.21 & 100 & \\
\hline
\end{tabular}

Note: a: Conversion factor is the stoichiometric ratio used to calculate carbon remineralization rates from net production or consumption rates of dissolved species based on stoichiometric organic matter oxidation reactions (Table 2). The carbon remineralization rates by $\mathrm{SO}_{4}^{2-}$ reduction was calculated from the production rates of excess $\mathrm{NH}_{4}^{+}$, i.e., rates that cannot be accounted for by Fe reduction. $b$ : Rates underestimated due to a lower sampling resolution.

Table 5. Depth-integrated net production rates $(R)$ of dissolved species, the corresponding $C_{\text {diag }}$ rates, and the relative importance of each process in diagenetic carbon oxidation in East China Sea sediments. Integration depth: $30 \mathrm{~cm}$.

\begin{tabular}{|c|c|c|c|c|c|}
\hline Carbon remineralization by: & $\begin{array}{c}R \\
\left(\mathbf{m m o l ~ m}^{-2} \mathbf{d}^{-1}\right) \\
\end{array}$ & 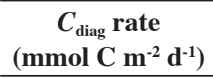 & $\begin{array}{c}\text { Relative importance } \\
(\%)\end{array}$ & Method & Reference \\
\hline Aerobic respiration & $\begin{array}{c}15.90 \pm 2.39 \\
(1.2-25.6)^{\mathrm{a}}\end{array}$ & $12.21 \pm 1.84$ & $63 \pm 15$ & $\mathrm{O}_{2}$ microelectrodes & Cai et al. 2014 \\
\hline $\mathrm{NO}_{3}^{-}$reduction & $\begin{array}{l}1.34 \pm 1.09 \\
(0.30-3.06)\end{array}$ & $1.68 \pm 1.36$ & $9 \pm 7$ & $\begin{array}{l}\text { Pore-water profiles analyzed by } \\
\text { PROFILE }\end{array}$ & Song et al. 2013 \\
\hline Mn oxides reduction & $\begin{array}{l}0.20 \pm 0.19 \\
(0.04-0.63)\end{array}$ & $0.10 \pm 0.09$ & $0.5 \pm 0.5$ & $\begin{array}{c}\text { Pore-water profiles analyzed by } \\
\text { PROFILE }\end{array}$ & Zhao et al. 2017 \\
\hline Fe oxides reduction & $\begin{array}{l}0.15 \pm 0.11 \\
(0.03-0.44)\end{array}$ & $0.04 \pm 0.03$ & $0.2 \pm 0.2$ & $\begin{array}{c}\text { Pore-water profiles analyzed by } \\
\text { PROFILE }\end{array}$ & Zhao et al. 2017 \\
\hline $\mathrm{SO}_{4}{ }^{2-}$ reduction & $\begin{array}{c}2.72 \pm 1.42 \\
(1.7-6.0) \\
\end{array}$ & $5.45 \pm 2.83$ & $28 \pm 15$ & ${ }^{35} \mathrm{~S}$, whole core incubation & Lin et al. 2000 \\
\hline Total & $20.31 \pm 2.99$ & $19.48 \pm 3.62$ & 100 & & \\
\hline
\end{tabular}

Note: $a$ : Numbers in the parentheses indicate minimum and maximum values. $b$ : The denitrification and dissimilatory nitrate reduction rates determined by ${ }^{15} \mathrm{~N}$ tracer experiments (Song et al.2013) are not included in the calculation due to the high concentration $\left(100 \mu \mathrm{mol} \mathrm{L}^{-1}\right)$ of ${ }^{15} \mathrm{NO}_{3}$ - applied in the incubation. 
$C_{\text {diag }}$ rate of $19.48 \pm 3.62 \mathrm{mmol} \mathrm{C} \mathrm{m}^{-2} \mathrm{~d}^{-1}$ for the ECS sediment in summer (Table 5), with the relative importance of different electron acceptors decreasing in the order of $\mathrm{O}_{2}(63$ $\pm 15 \%)>\mathrm{SO}_{4}{ }^{2-}(28 \pm 15 \%)>\mathrm{NO}_{3}^{-}(9 \pm 7 \%)>\mathrm{Mn}$ oxides $(0.5 \pm 0.5 \%) \approx \mathrm{Fe}$ oxides $(0.2 \pm 0.2 \%)$.

Comparison of the $C_{\text {diag }}$ data of SOT and ECS revealed several intriguing features. First, while the SOT sediments have TOC contents (0.4- - $.7 \%$; Kao et al. 2003) only slightly lower than those of ECS inner shelf sediments (0.4 - 1.0\%; Zhu et al. 2012), $C_{\text {diag }}$ rates of the former are one order of magnitude lower than the latter. Second, despite the distinct bottom-water $\mathrm{O}_{2}$ concentrations of the inner shelf (the cited $\mathrm{O}_{2}$ profiles of ECS sediment were not generated in the hypoxia region) and in the trough, aerobic respiration is the dominant redox process in both systems. Lastly, the relative importance of nitrate reduction in organic carbon oxidation is elevated in SOT compared with ECS sediments. Associations of these features to the quantity and quality of organic carbon, bottom-water conditions, and methodological limitations will be elaborated in succeeding text.

\subsection{Budget, Quality and Burial Efficiency of Organic Carbon}

To assess the quantity and quality of organic carbon, we first evaluated the benthic-pelagic carbon budget for the SOT and ECS regions (Fig. 4). The SOT has a clear component of vertical transport. The primary production at the trap station T6 is $24 \pm 1 \mathrm{mmol} \mathrm{C} \mathrm{m}^{-2} \mathrm{~d}^{-1}$ (Gong et al. 2000). Based on the sediment trap data (Sheu et al. 1999), lateral transport is present but mild under regular conditions (i.e., not during episodic flood events). The $C_{\text {proc }}$ (cf. section 2.5) is $5.2 \pm 2.3 \mathrm{mmol} \mathrm{C} \mathrm{m}^{-2} \mathrm{~d}^{-1}$, in agreement with the flux measured at $1346 \mathrm{~m}$ of Station T6.

Such a budget has already been presented previously for the ECS (Song et al. 2016). Here, we slightly modified the existing ECS budget by using our own estimates of $C_{\text {diag }}$ (Table 5) to cover the diagenetic activity of $30 \mathrm{~cm}$ sediment column. The $C_{\text {proc }}$ for the ECS is $26.3 \pm 8.0 \mathrm{mmol} \mathrm{C} \mathrm{m}^{-2} \mathrm{~d}^{-1}$, much lower than the trap-derived settling fluxes (200 $300 \mathrm{mmol} \mathrm{C} \mathrm{m}^{-2} \mathrm{~d}^{-1}$ in the inner shelf; Zhang et al. 2006) or the primary production $\left(78 \pm 53 \mathrm{mmol} \mathrm{C} \mathrm{m}^{-2} \mathrm{~d}^{-1}\right.$; Gong et al. 2003). The unbalanced budget reflects the steering role of lateral transport and resuspension, both of which are difficult to quantify, in governing the deposition and distribution of organic carbon on the shelf.

Because $C_{\text {proc }}$ is less sensitive to resuspension compared with sediment trap measurements, the quality of organic carbon is assessed by the ratio $C_{\text {diag }} / C_{\text {proc }}$. To take into account that $C_{\text {diag }}$ rates, like all microbial activities, are temperature dependent (Price and Sowers 2004), we first calculated the theoretical $C_{\text {diag }}$ value at $4^{\circ} \mathrm{C}\left(C_{\text {diag, }, 4^{\circ} \mathrm{C}}\right)$ assuming a temperature coefficient $\left(Q_{10}\right)$ of 2 :

$C_{\text {diag, } 4^{\circ} \mathrm{C}}=C_{\text {diag }} Q_{10}^{\left(4^{\circ} \mathrm{C}-T_{\text {initin }}\right) / 10^{\circ}}$

The in situ bottom-water temperature $\left(T_{\text {in situ }}\right)$ in summer is $20^{\circ} \mathrm{C}$ for the ECS (Song et al. 2016). The $C_{\text {diag, } 4^{\circ} \mathrm{C}}$ value of ECS $\left(6.4 \pm 1.2 \mathrm{mmol} \mathrm{C} \mathrm{m}^{-2} \mathrm{~d}^{-1}\right)$ remains significantly higher than that of SOT, but the $C_{\text {diag, } 4^{\circ} \mathrm{C}} / C_{\text {proc }}$ ratios (ECS, $0.24 \pm$ 0.09 ; SOT, $0.32 \pm 0.15$ ) no longer indicate a higher proportion of degradable organic carbon on the shelf. Accordingly, there is no conclusive evidence for a lower quality of organic
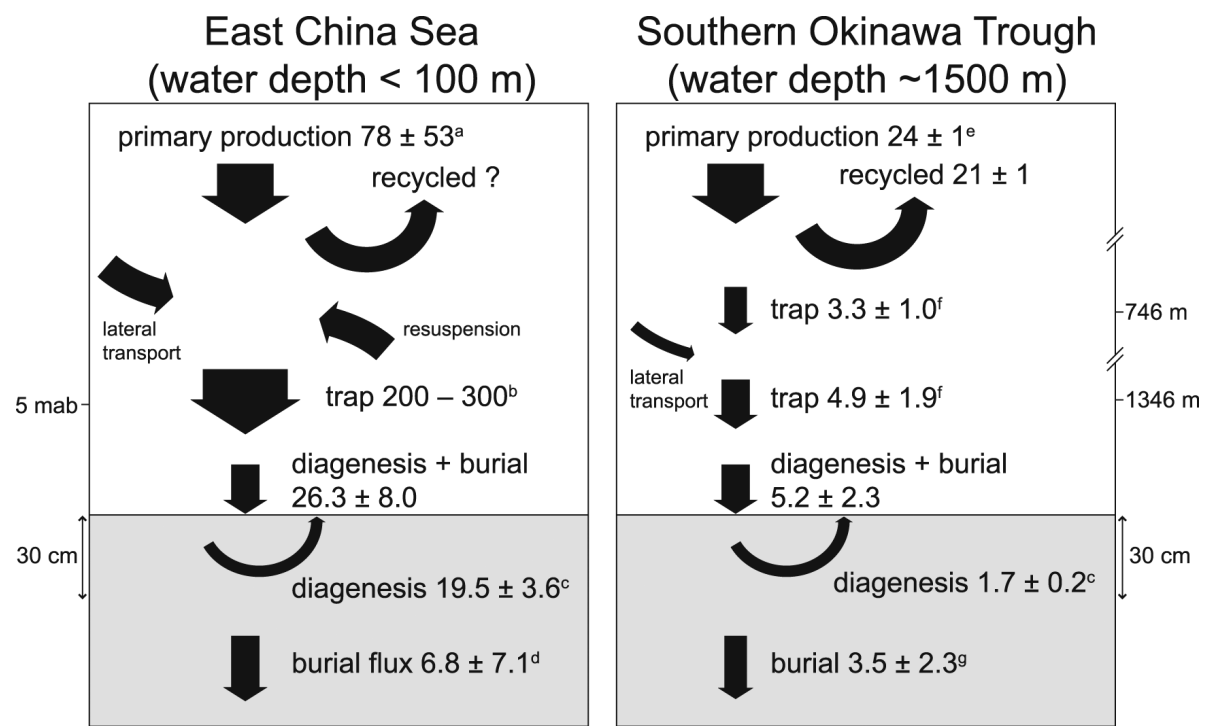

Fig. 4. A simple pelagic-benthic budget for organic carbon flux in the ECS and deep SOT. The fluxes are in the unit of $\mathrm{mmol} \mathrm{m}^{-2} \mathrm{~d}^{-1}$. Sources: a $=$ Gong et al. (2003); b = Zhang et al. (2006); c = this study; $d=$ Song et al. (2016); e = Gong et al. (2000); $f=$ Sheu et al. (1999); g = Lin et al. (2002a) and this study. Abbreviation: mab, meters above bottom. 
matter in the SOT. This finding seems to contradict the presumption that the SOT, being the terminal of cross-shelf sediment transport (Kao et al. 2003; Chen et al. 2017) and vertical deposition, should receive particles containing relatively refractory organic matter. Uncertainties in the estimates of $C_{\text {diag }}$, the use of an inappropriate $Q_{10}$ value, or the presence of unaccounted sources of labile carbon (e.g., fresh phytodetritus from the perennial upwelling center; Fig. 1) might result in the lack of a significant difference in the $C_{\text {diag, },{ }^{\circ} \mathrm{C}} / C_{\text {proc }}$ ratios between the two systems. Further degradation experiments are necessary to clarify this issue. Based on the existing data, we tentatively attribute the 10 -fold difference in $C_{\text {diag }}$ rate to different bottom-water temperature and carbon flux.

The burial efficiency, assessed by $C_{\text {burial }} / C_{\text {proc }} \times 100 \%$, is 68 and $26 \%$ for the SOT and ECS, respectively. With net sediment accumulation rates available for both regions (Su and Huh 2002; Li et al. 2012), their carbon preservation efficiency can be further compared with other major depositional systems around the world (Fig. 5; Blair and Aller 2012). The SOT plots next to continental boundaries fed by small mountain rivers, whereas the inner shelf of ECS dots the region defined for deltaic fluidized muds.

The proximity of the inner shelf sediments of ECS to deltaic fluidized muds in Fig. 5 alludes to the same controlling mechanism of the low carbon burial efficiency, i.e., prolonged exposure of particles to oxygen-rich water as a result of frequent sediment reworking and suspension (Blair and Aller 2012). The controlling mechanisms of the high carbon burial efficiency in the SOT are more complicated, including the factors of small mountain rivers and rifting. These two factors act differently in facilitating carbon burial. Small mountain rivers actively deliver deposits containing fossil organic carbon during storm events (Blair and Aller 2012), whereas rifting works passively via creating steep topographic gradients and deep basins. The steep gradients induce geofocusing of particles toward the bottom, whereas the deep water depth results in prolonged alteration of phytodetritus during vertical transport and suppressed microbial activities due to lowered bottom-water temperature (Price and Sowers 2004). The notion supported by previous studies, i.e., a major fraction of organic matter in SOT sediment originates from the inner shelf of ECS instead of rivers in northeastern Taiwan (Kao et al. 2003; Chen et al. 2017), argues in favor of a greater contribution from rifting over small mountain rivers. However, mineralogical evidence suggests that rivers in northeastern Taiwan (Fig. 1) provide massive clastic materials to the SOT (Diekmann et al. 2008), implying substantial contribution of fossil organic carbon to the high burial efficiency. To clarify whether and how rifting alone can elevate carbon sequestration, further study is warranted to investigate the early diagenesis of regular sediment in the central section of the Okinawa Trough, which is distant from major mountain rivers in Taiwan and Japan.

\subsection{Effects of Bottom-Water Conditions and Methodological Limitations}

The deep basin of SOT is a suboxic environment

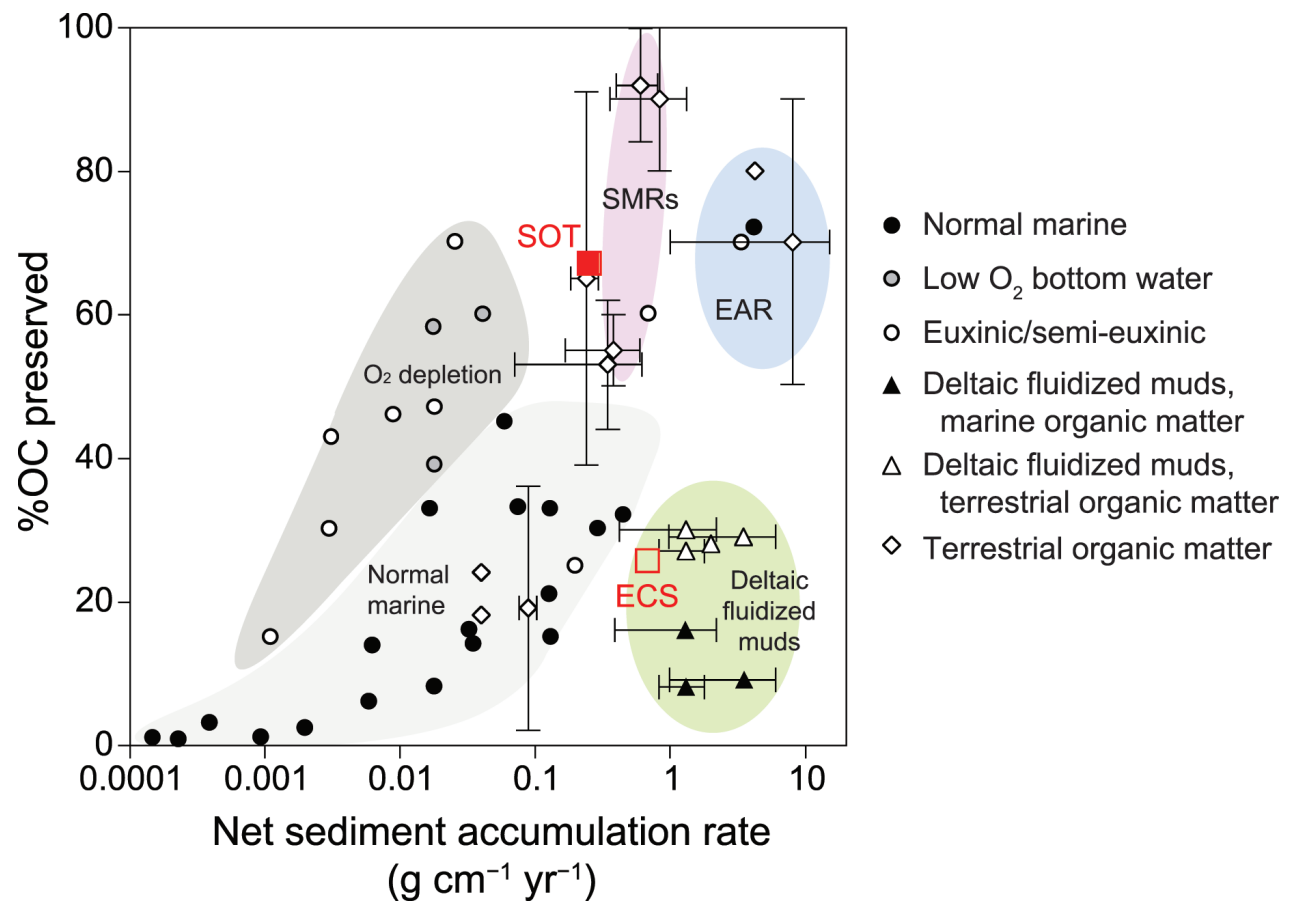

Fig. 5. The percentage of organic carbon (OC) preserved versus net sediment accumulation rate of the SOT, ECS (inner shelf), and major depositional environments (modified from Blair and Aller 2012). Abbreiviations: EAR, extreme accumulation rates; SMRs, small mountain rivers. 
with low $\mathrm{O}_{2}\left(66-69 \mu \mathrm{mol} \mathrm{L} \mathrm{L}^{-1}\right.$; Fig. 2a) and high $\mathrm{NO}_{3}$ (36 $\mu \mathrm{mol} \mathrm{L}^{-1}$; Wong et al. 1989) concentrations. This bottom-water condition is in contrast to that of the ECS, which is relatively enriched in $\mathrm{O}_{2}$ (mostly $>100 \mu \mathrm{mol} \mathrm{L}^{-1}$ except for the hypoxia region; Chen et al. 2007) and depleted in $\mathrm{NO}_{3}{ }^{-}$(mostly $<10 \mu \mathrm{mol} \mathrm{L}{ }^{-1}$; Gong et al. 2000). Hence, our findings of reduced contribution of $\mathrm{O}_{2}$ and elevated contribution of $\mathrm{NO}_{3}{ }^{-}$in the SOT, compared to those of the ECS, likely reflect the control of bottom-water conditions on the partitioning of carbon oxidation processes in near-surface sediment, as suggested by earlier modelling work (e.g., Soetaert et al. 1996).

Lastly, it is necessary to acknowledge the limitations of this pore-water profile-based approach in quantifying early diagenesis. First, it is not common to have the complete suite of redox-related dissolved species characterized in one single site. For example, the pore-water data from the ECS are collected from different sites. Given the high heterogeneity of shelf water and sediment, the composite partitioning scheme of carbon oxidation pathways might have errors larger than presented in Table 5. Second, it is wellknown that dissolved $\mathrm{Mn}^{2+}$ and $\mathrm{Fe}^{2+}$ profiles generally lead to underestimation of $\mathrm{Mn}$ and $\mathrm{Fe}$ oxides reduction (Canfield et al. 1993; Hyun et al. 2017). This is because $\mathrm{Mn}^{2+}$ and $\mathrm{Fe}^{2+}$ also accumulate in the solid phase, which represents the major fraction of the reduced pools. For example, the rates of $\mathrm{Fe}$ reduction calculated by the pore-water profiles of the East Sea sediments are two to three orders of magnitudes lower than those obtained via incubations (Hyun et al. 2017), and Fe reduction contributes up to $20 \%$ of carbon oxidation. Lastly, this approach does not consider the aerobic carbon remineralization contributed by faunal activities (i.e., $C_{\text {pre-burial }}$ in Reimers and Suess 1983), including bioturbation, bioirrigation and metabolic demands (Glud 2008; Snelgrove et al. 2018). Therefore, the partitioning of carbon oxidation pathways summarized in this study for the SOT and ECS sediments (Table 5) should be considered tentative. Additional studies using incubation-based techniques are sorely needed to revise the partitioning scheme, and to better estimate the $C_{\text {diag }}$ rate.

\section{CONCLUSION}

This study presents an examination of diagenetic activities and carbon remineralization based on the first complete suite of pore-water data of sediment marginally affected by hydrothermal activities in the SOT. Below is a summary of our main findings.

(1) The pore-water data show an oxygen penetration depth of $1 \mathrm{~cm}$, consumption of $\mathrm{NO}_{3}{ }^{-}$in the top $1 \mathrm{~cm}$, smeared profiles of $\mathrm{Mn}^{2+}$ and $\mathrm{Fe}^{2+}$ with the latter reaching up to $450 \mu \mathrm{mol} \mathrm{L}{ }^{-1}$, and relatively unchanged $\mathrm{SO}_{4}{ }^{2-}$ concentrations with depth. The remarkably high $\mathrm{Fe}^{2+}$ concentrations possibly reflect the incorporation of hydrothermal- ly derived reactive $\mathrm{Fe}$ into settling particles.

(2) Analysis of the pore-water profiles provides an estimate of $1.68 \pm 0.21 \mathrm{mmol} \mathrm{C} \mathrm{m}^{-2} \mathrm{~d}^{-1}$ as the total carbon remineralization rate in the upper $30 \mathrm{~cm}$ sediment column. The rate, about 10-fold lower than that of ECS, is attributed to the lower bottom-water temperature and carbon flux in the trough.

(3) Compared to the ECS, the relative importance of $\mathrm{O}_{2}$ and $\mathrm{NO}_{3}{ }^{-}$as electron acceptors is reduced and enhanced, respectively, in the SOT, reflecting the control of bottomwater conditions on early diagenesis. However, aerobic respiration remains the major carbon oxidation pathway.

(4) The SOT has a carbon burial efficiency of $68 \%$, and plots close to continental boundaries fed by small mountain rivers on the carbon preservation-mass accumulation graph. The high carbon burial efficiency reflects the combined effects of small mountain rivers and riftinginduced particle geofocusing and refrigerating.

Acknowledgements We thank the captains and crews of the R/V Ocean Researcher I for their competent work. We are grateful to Bing-Rong Jiang, Shu-Han Chang, ShengTing Hsu, and Yi-Jyun Chen for their assistance on sampling and lab work, and Ai-Lin Lyu for logistic support. We thank the two anonymous reviewers for their constructive comments. This work was financed by the Central Geologic Survey, Ministry of Economic Affairs.

\section{REFERENCES}

Aller, R. C., 2014: Sedimentary diagenesis, depositional environments, and benthic fluxes. In: Holland, H. D. and K. K. Turekian (Eds.), Treatise on Geochemistry, Second Edition, Vol. 8, Elsevier, Amsterdam, 293-334, doi: 10.1016/B978-0-08-095975-7.00611-2. [Link]

American Public Health Association, American Water Works Association and Water Environment Federation, 1998: Standard Methods for the Examination of Water and Wastewater, Method 4500-S ${ }^{2-}$ sulfide, American Public Health Association, Washington, D.C., USA, 1220 pp.

Bakker, J. F. and W. Helder, 1993: Skagerrak (northeastern North Sea) oxygen microprofiles and porewater chemistry in sediments. Mar. Geol., 111, 299-321, doi: 10.1016/0025-3227(93)90137-K. [Link]

Berg, P., N. Risgaard-Petersen, and S. Rysgaard, 1998: Interpretation of measured concentration profiles in sediment pore water. Limnol. Oceanogr., 43, 1500-1510, doi: 10.4319/lo.1998.43.7.1500. [Link]

Berndt, C., C. Hensen, C. Mortera-Gutierrez, S. Sarkar, S. Geilert, M. Schmidt, V. Liebetrau, R. Kipfer, F. Scholz, M. Doll, S. Muff, J. Karstens, S. Planke, S. Petersen, C. Böttner, W.-C. Chi, M. Moser, R. Behrendt, A. Fiskal, M. A. Lever, C. C. Su, L. Deng, M. 
S. Brennwald, and D. Lizarralde, 2016: Rifting under steam-How rift magmatism triggers methane venting from sedimentary basins. Geology, 44, 767-770, doi: 10.1130/G38049.1. [Link]

Blair, N. E. and R. C. Aller, 2012: The fate of terrestrial organic carbon in the marine environment. Annu. Rev. Mar. Sci., 4, 401-423, doi: 10.1146/annurev-marine-120709-142717. [Link]

Blum, P., 1997: Physical properties handbook: A guide to the shipboard measurement of physical properties of deep-sea cores. ODP Technical Note 26, doi: 10.2973/ odp.tn.26.1997. [Link]

Boudreau, B. P., 1987: A steady-state diagenetic model for dissolved carbonate species and $\mathrm{pH}$ in the porewaters of oxic and suboxic sediments. Geochim. Cosmochim. Acta, 51, 1985-1996, doi: 10.1016/00167037(87)90187-6. [Link]

Cai, P., X. Shi, W. S. Moore, S. Peng, G. Wang, and M. Dai, 2014: ${ }^{224} \mathrm{Ra}:{ }^{228} \mathrm{Th}$ disequilibrium in coastal sediments: Implications for solute transfer across the sedimentwater interface. Geochim. Cosmochim. Acta, 125, 6884, doi: 10.1016/j.gca.2013.09.029. [Link]

Calvert, S. E., 1966: Accumulation of diatomaceous silica in the sediments of the Gulf of California. Geol. Soc. Am. Bull., 77, 569-596, doi: 10.1130/0016-7606(1966)77 [569:AODSIT] 2.0.CO;2. [Link]

Canfield, D. E., B. Thamdrup, and J. W. Hansen, 1993: The anaerobic degradation of organic matter in Danish coastal sediments: Iron reduction, manganese reduction, and sulfate reduction. Geochim. Cosmochim. Acta, 57, 3867-3883, doi: 10.1016/0016-7037(93)90340-3. [Link]

Chen, C. C., G. C. Gong, and F. K. Shiah, 2007: Hypoxia in the East China Sea: One of the largest coastal low-oxygen areas in the world. Mar. Environ. Res., 64, 399408, doi: 10.1016/j.marenvres.2007.01.007. [Link]

Chen, C.-T. A., S. Kandasamy, Y. P. Chang, Y. Bai, X. He, J. T. Lu, and X. Gao, 2017: Geochemical evidence of the indirect pathway of terrestrial particulate material transport to the Okinawa Trough. Quat. Int., 441, 5161, doi: 10.1016/j.quaint.2016.08.006. [Link]

Chou, Y.-C., C.-C. Wang, H.-H. Chen, and Y.-H. Lin, 2019: Seafloor characterization in the southernmost Okinawa Trough from underwater optical imagery. Terr. Atmos. Ocean. Sci., 30, 717-737, doi: 10.3319/ TAO.2019.03.14.01. [Link]

De Beer, D., M. Haeckel, J. Neumann, G. Wegener, F. Inagaki, and A. Boetius, 2013: Saturated $\mathrm{CO}_{2}$ inhibits microbial processes in $\mathrm{CO}_{2}$-vented deep-sea sediments. Biogeosciences, 10, 5639-5649, doi: 10.5194/ bg-10-5639-2013. [Link]

Diekmann, B., J. Hofmann, R. Henrich, D. K. Fütterer, U. Röhl, and K. Y. Wei, 2008: Detrital sediment supply in the southern Okinawa Trough and its relation to sea-level and Kuroshio dynamics during the late Quaternary. Mar. Geol., 255, 83-95, doi: 10.1016/j.margeo.2008.08.001. [Link]

Emerson, S., R. Jahnke, M. Bender, P. Froelich, G. Klinkhammer, C. Bowser, and G. Setlock, 1980: Early diagenesis in sediments from the Eastern Equatorial Pacific, I. Pore water nutrient and carbonate results. Earth Planet. Sci. Lett., 49, 57-80, doi: 10.1016/0012821X(80)90150-8. [Link]

Glasby, G. P. and K. Notsu, 2003: Submarine hydrothermal mineralization in the Okinawa Trough, SW of Japan: An overview. Ore Geol. Rev., 23, 299-339, doi: 10.1016/j.oregeorev.2003.07.001. [Link]

Glud, R. N., 2008: Oxygen dynamics of marine sediments. Mar. Biol. Res., 4, 243-289, doi: 10.1080/17451000801888726. [Link]

Gong, G.-C., F.-K. Shiah, K.-K. Liu, Y.-H. Wen, and M.-H. Liang, 2000: Spatial and temporal variation of chlorophyll $a$, primary productivity and chemical hydrography in the southern East China Sea. Cont. Shelf Res., 20, 411-436, doi: 10.1016/S0278-4343(99)00079-5. [Link]

Gong, G.-C., Y.-H. Wen, B.-W. Wang, and G.-J. Liu, 2003: Seasonal variation of chlorophyll $a$ concentration, primary production and environmental conditions in the subtropical East China Sea. Deep-Sea Res. Part II-Top. Stud. Oceanogr., 50, 1219-1236, doi: 10.1016/S09670645(03)00019-5. [Link]

Helder, W., 1989: Early diagenesis and sediment-water exchange in the Savu Basin (Eastern Indonesia). Neth. J. Sea Res., 24, 555-572, doi: 10.1016/00777579(89)90133-6. [Link]

Hsu, H.-H., L.-F. Lin, C.-S. Liu, J.-H. Chang, W.-Z. Liao, T.-T. Chen, K.-H. Chao, S.-L. Lin, H.-S. Hsieh, and S.C. Chen, 2019: Pseudo-3D seismic imaging of Geolin Mounds hydrothermal field in the Southern Okinawa Trough offshore NE Taiwan. Terr. Atmos. Ocean. Sci., 30, 705-716, doi: 10.3319/TAO.2019.03.14.02. [Link]

Hsu, S. C., F. J. Lin, W. L. Jeng, Y. C. Chung, and L. M. Shaw, 2003: Hydrothermal signatures in the southern Okinawa Trough detected by the sequential extraction of settling particles. Mar. Chem., 84, 49-66, doi: 10.1016/S0304-4203(03)00102-6. [Link]

Huh, C. A., C. C. Su, C. H. Wang, S. Y. Lee, and I. T. Lin, 2006: Sedimentation in the Southern Okinawa Trough - Rates, turbidites and a sediment budget. Mar. Geol., 231, 129-139, doi: 10.1016/j.margeo.2006.05.009. [Link]

Hyun, J. H., S. H. Kim, J. S. Mok, H. Cho, T. Lee, V. Vandieken, and B. Thamdrup, 2017: Manganese and iron reduction dominate organic carbon oxidation in surface sediments of the deep Ulleung Basin, East Sea. Biogeosciences, 14, 941-958, doi: 10.5194/bg-14-9412017. [Link] 
Inagaki, F., M. M. M. Kuypers, U. Tsunogai, J. Ishibashi, K. Nakamura, T. Treude, S. Ohkubo, M. Nakaseama, K. Gena, H. Chiba, H. Hirayama, T. Nunoura, K. Takai, B. B. Jørgensen, K. Horikoshi, and A. Boetius, 2006: Microbial community in a sediment-hosted $\mathrm{CO}_{2}$ lake of the southern Okinawa Trough hydrothermal system. Proc. Natl. Acad. Sci., 103, 14164-14169, doi: 10.1073/pnas.0606083103. [Link]

Kao, S. J., F. J. Lin, and K. K. Liu, 2003: Organic carbon and nitrogen contents and their isotopic compositions in surficial sediments from the East China Sea shelf and the southern Okinawa Trough. Deep-Sea Res. Part II-Top. Stud. Oceanogr., 50, 1203-1217, doi: 10.1016/ S0967-0645(03)00018-3. [Link]

Konno, U., U. Tsunogai, F. Nakagawa, M. Nakaseama, J. Ishibashi, T. Nunoura, and K. Nakamura, 2006: Liquid $\mathrm{CO}_{2}$ venting on the seafloor: Yonaguni Knoll IV hydrothermal system, Okinawa Trough. Geophys. Res. Lett., 33, L16607, doi: 10.1029/2006GL026115. [Link]

Küster-Heins, K., G. J. de Lange, and M. Zabel, 2010: Benthic phosphorus and iron budgets for three NW African slope sediments: A balance approach. Biogeosciences, 7, 469-480, doi: 10.5194/bg-7-469-2010. [Link]

Lee, H. F., 2004: Compositions of Fumarolic Gases and the H-O Isotopic Ratios of the Condensed Water in Tatun Volcanic Area, North Taiwan. Master Thesis, Institute of Geoscience, National Taiwan University, Taipei City, Taiwan, 83 pp, doi: 10.6342/NTU.2004.02083. (in Chinese) [Link $]$

Li, J., B. Hu, Y. Dou, J. Zhao, and G. Li, 2012: Modern sedimentation rate, budget and supply of the muddy deposits in the East China Seas. Geological Review, 58, 745-756. (in Chinese)

Lin, S., K. M. Huang, and S. K. Chen, 2000: Organic carbon deposition and its control on iron sulfide formation of the southern East China Sea continental shelf sediments. Cont. Shelf Res., 20, 619-635, doi: 10.1016/ S0278-4343(99)00088-6. [Link]

Lin, S., K. M. Huang, and S. K. Chen, 2002a: Sulfate reduction and iron sulfide mineral formation in the southern East China Sea continental slope sediment. Deep-Sea Res. Part I-Oceanogr. Res. Pap., 49, 1837-1852, doi: 10.1016/S0967-0637(02)00092-4. [Link]

Lin, S., I. J. Hsieh, K. M. Huang, and C. H. Wang, 2002b: Influence of the Yangtze River and grain size on the spatial variations of heavy metals and organic carbon in the East China Sea continental shelf sediments. Chem. Geol., 182, 377-394, doi: 10.1016/S00092541(01)00331-X. [Link]

Lin, Y. S., V. B. Heuer, T. Goldhammer, M. Y. Kellermann, M. Zabel, and K. U. Hinrichs, 2012: Towards constraining $\mathrm{H}_{2}$ concentration in subseafloor sediment: A proposal for combined analysis by two distinct approaches. Geochim. Cosmochim. Acta, 77, 186-201, doi: 10.1016/j.gca.2011.11.008. [Link]

Lin, Y. S., B. P. Koch, T. Feseker, K. Ziervogel, T. Goldhammer, F. Schmidt, M. Witt, M. Y. Kellermann, M. Zabel, A. Teske, and K. U. Hinrichs, 2017: Near-surface heating of young rift sediment causes mass production and discharge of reactive dissolved organic matter. Sci.Rep., 7, doi: 10.1038/srep44864. [Link]

Liu, K. K., G. C. Gong, S. Lin, C. Y. Yang, C. L. Wei, S. C. Pai, and C. K. Wu, 1992: The year-round upwelling at the shelf break near the northern tip of Taiwan as evidenced by chemical hydrography. Terr. Atmos. Ocean. Sci., 3, 243-276, doi: 10.3319/ TAO.1992.3.3.243(KEEP). [Link]

Lizarralde, D., S. A. Soule, J. S. Seewald, and G. Proskurowski, 2011: Carbon release by off-axis magmatism in a young sedimented spreading centre. Nat. Geosci., 4, 50-54, doi: 10.1038/ngeo1006. [Link]

Mottl, M. J., 2005: Data report: Composition of pore water from Site 1202, southern Okinawa Trough. In: Shinohara, M., M. H. Salisbury, and C. Richter (Eds.), Proceedings of the Ocean Drilling Program, Scientific Results, 195. Available at http://www-odp.tamu.edu/ publications/195 SR/107/107.htm.

Price, P. B. and T. Sowers, 2004: Temperature dependence of metabolic rates for microbial growth, maintenance, and survival. Proc. Natl. Acad. Sci., 101, 4631-4636, doi: 10.1073/pnas.0400522101. [Link]

Reimers, C. E. and E. Suess, 1983: The partitioning of organic carbon fluxes and sedimentary organic matter decomposition rates in the ocean. Mar. Chem., 13, 141-168, doi: 10.1016/0304-4203(83)90022-1. [Link]

Sakai, H., T. Gamo, E. Kim, K. Shitashima, F. Yanagisawa, M. Tsutsumi, J. Ishibashi, Y. Sano, H. Wakita, T. Tanaka, T. Matsumoto, T. Naganuma, and K. Mitsuzawa, 1990: Unique chemistry of the hydrothermal solution in the Mid-Okinawa Trough backarc basin. Geophys. Res. Lett., 17, 2133-2136, doi: 10.1029/ GL017i012p02133. [Link]

Seeberg-Elverfeldt, J., M. Schlüter, T. Feseker, and M. Kölling, 2005: Rhizon sampling of porewaters near the sediment-water interface of aquatic systems. Limnol. Oceanogr. Meth., 3, 361-371, doi: 10.4319/ lom.2005.3.361. [Link]

Sheu, D. D., W. C. Jou, Y. C. Chung, T. Y. Tang, and J. J. Hung, 1999: Geochemical and carbon isotopic characterization of particles collected in sediment traps from the East China Sea continental slope and the Okinawa Trough northeast of Taiwan. Cont. Shelf Res., 19, 183203, doi: 10.1016/S0278-4343(98)00081-8. [Link]

Sibuet, J. C., B. Deffontaines, S. K. Hsu, N. Thareau, J. P. Le Formal, and C. S. Liu, 1998: Okinawa trough backarc basin: Early tectonic and magmatic evolution. J. Geophys. Res., 103, 30245-30267, doi: 10.1029/98JB01823. [Link] 
Snelgrove, P. V. R., K. Soetaert, M. Solan, S. Thrush, C.L. Wei, R. Danovaro, R. W. Fulweiler, H. Kitazato, B. Ingole, A. Norkko, R. J. Parkes, and N. Volkenborn, 2018: Global carbon cycling on a heterogeneous seafloor.Trends Ecol.Evol., 33,96-105, doi: 10.1016/j. tree.2017.11.004. [Link]

Soetaert, K., P. M. Herman, and J. J. Middelburg, 1996: A model of early diagenetic processes from the shelf to abyssal depths. Geochim. Cosmochim. Acta, 60, 10191040, doi: 10.1016/0016-7037(96)00013-0. [Link]

Song, G. D., S. M. Liu, H. Marchant, M. M. M. Kuypers, and G. Lavik, 2013: Anammox, denitrification and dissimilatory nitrate reduction to ammonium in the East China Sea sediment. Biogeosciences, 10, 6851-6864, doi: 10.5194/bg-10-6851-2013. [Link]

Song, G. D., S. Liu, Z. Zhu, W. Zhai, C. Zhu, and J. Zhang, 2016: Sediment oxygen consumption and benthic organic carbon mineralization on the continental shelves of the East China Sea and the Yellow Sea. Deep-Sea Res. Part II-Top. Stud. Oceanogr., 124, 53-63, doi: 10.1016/j.dsr2.2015.04.012. [Link]

$\mathrm{Su}$, C.-C. and and C.-A. Huh, 2002: ${ }^{210} \mathrm{~Pb},{ }^{137} \mathrm{Cs}$ and ${ }^{239,240} \mathrm{Pu}$ in East China Sea sediments: Sources, pathways and budgets of sediments and radionuclides. Mar. Geol., 183,
163-178, doi: 10.1016/s0025-3227(02)00165-2. [Link] Thunell, R. C., C. J. Pride, E. Tappa, and F. E. Muller-Karger, 1994: Biogenic silica fluxes and accumulation rates in the Gulf of California. Geology, 22, 303-306, doi: 10.1130/0091-7613(1994)022<0303:BSFAAR>2.3. $\mathrm{CO} ; 2$. [Link]

Wong, G. T. F., S. C. Pai, and C. T. A. Chen, 1989: Chemical hydrography across the East China Sea - Kuroshio frontal region, northeast of Taiwan. Acta Oceanogr. Taiwan, 23, 1-18.

Zhang, Y., F. Zhang, X. Guo, and M. Zhang, 2006: Autumn flux of particle settling observed at three representative stations in East China Sea. Oceanologia et Limnologia Sinica, 37, 28-34. (in Chinese)

Zhao, B., P. Yao, T. S. Bianchi, Y. Xu, H. Liu, T. Mi, X. H. Zhang, J. Liu, and Z. Yu, 2017: Early diagenesis and authigenic mineral formation in mobile muds of the Changjiang Estuary and adjacent shelf. J. Mar. Syst., 172, 64-74, doi: 10.1016/j.jmarsys.2017.03.001. [Link]

Zhu, M. X., X. C. Hao, X. N. Shi, G. P. Yang, and T. Li, 2012: Speciation and spatial distribution of solidphase iron in surface sediments of the East China Sea continental shelf. Appl. Geochem., 27, 892-905, doi: 10.1016/j.apgeochem.2012.01.004. [Link] 